\title{
Diagnosis and management of primary hyperparathyroidism - A scientific statement from the Department of Bone Metabolism, the Brazilian Society for Endocrinology and Metabolism
}

\author{
Diagnóstico e manejo do hiperparatireoidismo primário - Uma \\ posição científica do Departamento de Metabolismo Ósseo, \\ a Sociedade Brasileira de Endocrinologia e Metabolismo
}

Francisco Bandeira' ', Luiz Griz' ', Narriane Chaves' ', Nara Crispim

Carvalho', Lívia Maria Borges', Marise Lazaretti-Castro², Victoria Borba', Luiz Cláudio de Castro ${ }^{4}$, João Lindolfo Borges ${ }^{5}$, John Bilezikian ${ }^{6}$

\footnotetext{
1 Division of Endocrinology, Diabetes and Bone Diseases, Agamenon Magalhaes Hospital, Ministry of Health, University of Pernambuco (UPE) Medical School, Recife, PE, Brazil ${ }^{2}$ Division of Endocrinology, Federal University of São Paulo (Unifesp) Medical School, São Paulo, SP, Brazil

${ }^{3}$ Division of Endocrinology, Federal University of Parana (UFPR) Medical School, Curitiba, PR, Brazil

${ }^{4}$ Division of Pediatric Endocrinology, University of Brasilia (UnB) Medical School, Brasilia, DF, Brazil

${ }^{5}$ Division of Endocrinology, Catholic University of Brasilia (UCB), Brasilia, DF, Brazil ${ }^{6}$ Division of Endocrinology, Metabolic Bone Diseases Unit, College of Physicians \& Surgeons, Columbia University, New York, NY, USA
}

Division of Endocrinology, Diabetes and Bone Diseases, Agamenon Magalhaes Hospital, Ministry of Health, University of Pernambuco Medical School, Recife, PE, Brazil

Correspondence to: Nara Crispim Carvalho naranc@gmail.com

Received on Dec/27/2012 Accepted on May/3/2013

\begin{abstract}
Objective: To conduct a literature review on the diagnosis and management of primary hyperparathyroidism including the classical hipercalcemic form as well as the normocalcemic variant. Materials and methods: This scientific statement was generated by a request from the Brazilian Medical Association (AMB) to the Brazilian Society for Endocrinology as part of its Clinical Practice Guidelines program. Articles were identified by searching in PubMed and Cochrane databases as well as abstracts presented at the Endocrine Society, Brazilian Society for Endocrinology Annual Meetings and the American Society for Bone and Mineral Research Annual Meeting during the last 5 years. Grading quality of evidence and strength of recommendation were adapted from the first report of the Oxford Centre for Evidence-based Medicine. All grades of recommendation, including " $D$ ", are based on scientific evidence. The differences between $A, B, C$ and $D$, are due exclusively to the methods employed in generating evidence. Conclusion: We present a scientific statement on primary hyperparathyroidism providing the level of evidence and the degree of recommendation regarding causes, clinical presentation as well as surgical and medical treatment. Arq Bras Endocrinol Metab. 2013;57(6):406-24
\end{abstract}

Keywords

Primary hyperparathyroidism; normocalcemic primary hyperparathyroidism; diagnosis; treatment; parathyroidectomy

\section{RESUMO}

Objetivo: Conduzir uma atualização das últimas evidências científicas a respeito da apresentação, do diagnóstico e do manejo clínico e cirúrgico do hiperparatireoidismo primário clássico e normocalcêmico. Materiais e métodos: Este documento foi concebido pelo Departamento de Metabolismo Ósseo da Sociedade Brasileira de Endocrinologia e Metabologia (SBEM) a partir daquele oriundo do Programa de Diretrizes da Associação Médica Brasileira (AMB) da SBEM. Realizamos uma revisão dos artigos mais relevantes obtidos nos bancos de dados PubMed e Cochrane, além de abstracts apresentados nos encontros anuais da Endocrine Society, da Sociedade Brasileira de Endocrinologia e da American Society for Bone and Mineral Research dos últimos cinco anos, e classificamos as evidências em níveis de recomendações de acordo com a força científica por tipo de estudo, adaptando o primeiro relato do "Oxford Centre for Evidence-based Medicine".Todos os graus de recomendação, incluindo-se o " $\mathrm{D}$ ", foram baseados em evidência científica, sendo as diferenças entre o A, B, C e D devidas exclusivamente ao desenho empregado na geração da evidência. Conclusão: Apresentamos uma atualização científica a respeito do hiperparatireoidismo primário, classificando e graduando em níveis de recomendações as principais evidências científicas sobre as suas causas, as variadas formas de apresentação, seu diagnóstico e tratamento. Arq Bras Endocrinol Metab. 2013;57(6):406-24

\section{Descritores}

Hiperparatireoidismo primário; hiperparatireoidismo primário normocalcêmico; diagnóstico; tratamento; paratireoidectomia 


\section{INTRODUCTION}

$\mathrm{P}$ rimary hyperparathyroidism (PHPT) is a disease caused by overactive parathyroid glands with consequent hypercalcemia (1). The main cause in $85 \%-90 \%$ of cases, is the presence of a solitary parathyroid adenoma $(2,3)$. In the other affected patients, hyperplasia or multiple adenomas occur, the latter common in familial forms (3). PHPT occurs most commonly in individuals over 50 years of age and in postmenopausal women, showing a prevalence of about $0.78 \%$ in patients evaluated in reference services (4). Although the clinical presentation is variable the asymptomatic hypercalcemia form, detected by routine screening, is the most common $(50 \%$ to $80 \%)(2)$. However, the presentation is variable, with patients demonstrating a range from normocalcemia to severe hypercalcemic PHPT (1).

\section{METHODS}

This scientific statement was generated by a request from the Brazilian Medical Association (AMB) to the Brazilian Society for Endocrinology as part of its Clinical Practice Guidelines program. Through the Brazilian Society for Endocrinology's Department of Bone Metabolism, a task force was established. A draft of this report was submitted for comment to the membership of the Brazilian Medical Association and Brazilian Society of Endocrinology. This report represents the completion of this process.

Grading quality of evidence and strength of recommendation were adapted from the first report of the Oxford Centre for Evidence-Based Medicine, detailed described elsewhere (5) and summarized in table 1. Grades of recommendation are reported, as follows:

A: more consistent experimental or observational trials.

B: less consistent experimental or observational trials.

C: case reports (non-controlled trials).

D: opinion without critical evaluation, based on consensus, physiological studies or animal models.

Articles were identified by searching in PubMed and Cochrane databases as well as abstracts presented at the Endocrine Society and Brazilian Society for Endocrinology Annual Meetings and the American Society for Bone and Mineral Research Annual Meeting during the last 5 years. References are listed numerically in order of appearance in the text, followed by the levels of evidence.
Table 1. Grades of recommendation and strength scientific evidence

\begin{tabular}{|c|c|c|}
\hline \multirow[t]{4}{*}{ A } & $1 \mathrm{~A}$ & Systematic review of $\mathrm{RCT}^{\star}$ \\
\hline & & Systematic reviews of prospective cohort studies \\
\hline & $1 \mathrm{~B}$ & Individual RCT* with narrow confidence interval \\
\hline & & Prospective cohort studies \\
\hline \multirow[t]{5}{*}{ B } & $2 \mathrm{~A}$ & Systematic review of retrospective cohort studies \\
\hline & $2 \mathrm{~B}$ & $\mathrm{RCT}^{*}$ with $>20 \%$ dropout \\
\hline & & Retrospective cohort studies \\
\hline & $3 \mathrm{~A}$ & Systematic review of case-control studies \\
\hline & $3 B$ & Individual case-control studies \\
\hline C & 4 & Case series \\
\hline D & 5 & Expert opinion \\
\hline
\end{tabular}

${ }^{*} \mathrm{RCT}$ : randomized controlled trials.

\section{ETIOLOGY OF PRIMARY HYPERPARATHYROIDISM}

PHPT occurs due to unregulated and excessive parathyroid hormone $(\mathrm{PTH})$ secretion by one or more parathyroid glands (1).

Solitary parathyroid adenomas represent about $85 \%$ to $90 \%$ of PHPT cases $(1,2)(\mathbf{C}-\mathbf{4})$. In most other cases, multiple hyperfunctioning parathyroid glands occur, including hyperplasia and multiple adenomas $(3,6)(\mathbf{C}-4)$. Multiple gland disease is the most common finding in individuals with familial hyperparathyroidism syndromes, which corresponds to about $10 \%$ of all cases (3) (C-4). Parathyroid carcinoma rarely occurs and is responsible for only $0.7 \%$ of all cases (2) (C-4) (Table 2).

Table 2. Causes of primary hyperparathyroidism

Pathological conditions related to familial/isolated PHPT ${ }^{\star}$

Single adenomas (85\%)

Hyperplasia and multiple adenomas (15\%)

Carcinomas (0.5\%)

Clinical conditions associated to familial PHPT*

MEN** type 1 and 2

Hyperparathyroidism-jaw tumor syndrome

Familial isolated hyperparathyroidism

* Primary hyperparathyroidism; * Multiple endocrine neoplasia.

Familial primary hyperparathyroidism relates to various pathological entities, including multiple endocrine neoplasia type 1 (MEN 1) and type 2 (MEN 2), hyperparathyroidism-jaw tumor syndrome, and isolated familial hyperparathyroidism (7) (Table 2).

Despite MENl being a rare cause of PHPT, occurring in $2 \%-4 \%$ of cases, PHPT is the most common endocrine disorder in this disease, being present in virtually $100 \%$ of patients older than 50 years, and being the first 
sign of the multiglandular syndrome in most patients between 20 and 30 years $(8)$. Therefore, the diagnosis of PHPT in young adults should stimulate a search for MEN1, including their first-degree relatives (7) (D).

The prevalence of PHPT in MEN2A is lower than in MENl, occurring in 20\%-30\% of cases. In addition, most patients with PHPT present more discrete clinical features than those that occur in patients with MENI (9) (C-4).

Hyperparathyroidism-jaw tumor syndrome is a rare disease where jaw bone tumors associated with PHPT are found. Parathyroid cancer has been diagnosed in more than $15 \%$ of the cases $(9)(\mathbf{C}-4)$.

In isolated familial hyperparathyroidism, close relatives are diagnosed in the absence of other endocrinopathies. This familial variant of PHPT may correspond to a phenotype of syndromes such as subclinical MENI and MEN2 (8).

Severe neonatal hyperparathyroidism is a rare condition in which newborns have severe hypercalcemia associated with high levels of PTH, muscle hypotonia and respiratory distress. It usually occurs due to the presence of homozygous inactivating mutation of calcium sensing receptor gene (10).

Some situations that may explain the appearance of PHPT, such as irradiation or rare genetic abnormalities, can be identified in a small percentage of patients (11-14) (C-4). A cohort study conducted with workers at the Chernobyl nuclear plant in 1986, demonstrated that subsequent PHPT developed in 15 of the 61 individuals (OR 63.4, 95\% CI 35.7-112.5). The average radiation dose received was 0.3 to $8.7 \mathrm{~Gy}(13)(\mathbf{B}-2 \mathrm{~B})$.

PHPT has also been reported in patients receiving radiation in benign situations. A study of $2,555 \mathrm{pa}-$ tients receiving doses as low as 0.5 Gy before the age of 16 , followed for 50 years, showed a dose-dependent increased risk of PHPT (14) (B-2B). When patients with sporadic PHPT (389 patients) were compared to patients with a history of irradiation (49 patients), in a retrospective study, no difference in the clinical presentation, pathology or recurrence was observed over a 6-year follow-up period (15) (B-3B). However, exposed patients may have concomitant thyroid nodules which can also be related to intrathyroid parathyroid lesions (16) (B-3B).

In relation to radioiodine therapy, the incidence of PHPT was not increased significantly in a prospective study of 125 patients with thyrotoxicosis treated with $\mathrm{I}^{131}$, after a 21-year follow-up (17) (C-4).
Abnormalities in growth factor genes, proto-oncogenes or tumor suppressor genes have been associated with the development of parathyroid tumors. Among the genes involved are the PRADl/cyclin Dl gene for sporadic tumors (18-21) (C-4), RET for familial tumors $(22,23)(\mathbf{C}-4)$, and $\operatorname{MENl}(24,25)(\mathbf{C}-4)$ and HRPT $(13,14)(\mathbf{C}-4)$ for both sporadic and familial tumors.

The vitamin D receptor gene (VDR) may play a role in controlling the appearance of parathyroid adenomas, possibly due to the actions of 1,25-dihydroxyvitamin $\mathrm{D}$ to inhibit parathyroid cell proliferation in culture medium. While of interest, and presenting a plausible etiology, VDR gene inactivation does not seem to have a primary role in parathyroid gland tumorigenesis (26). However, vitamin D deficiency can alter the phenotypic expression of parathyroid tumors (27) (C-4).

Some small studies have also shown that defects in the Wnt $/ \beta$-Catenin signaling pathway are associated with the appearance of $\operatorname{PHPT}(28,29)(\mathbf{C}-4)$, but these findings need validation in larger studies.

\section{DIAGNOSIS OF PRIMARY HYPERPARATHYROIDISM}

Excessive secretion of PTH from one or more parathyroid glands causes hypercalcemia and constitutes the biochemical hallmark of PHPT (30). The finding of reproducible hypercalcemia in routine biochemical tests is a clue to the diagnosis of PHPT, especially in individuals over 50 years old and in postmenopausal women (31). About $40 \%$ of serum calcium is bound to albumin and serum levels, thus, should be adjusted using the formula: corrected calcium = serum calcium found in $\mathrm{mg} / \mathrm{dL}+[0.8 \times(4$-serum albumin $)]$. The measurement of ionized calcium could be useful in selected cases such as in patients with hyper- or hypoalbuminemia, thrombocytosis, Waldenström macroglobulinemia and myeloma. In the latter two instances, hypercalcemia may be present but the ionized serum calcium is normal (artifactual hypercalcemia) $(32,33)$ (C-4).

A cohort study based on the population of Tayside used the following biochemical criteria for diagnosing PHPT: 1) albumin-corrected serum calcium $>10.22$ $\mathrm{mg} / \mathrm{dL}$ (reference values: $8.4-10.22 \mathrm{mg} / \mathrm{dL}$ ) at least on 2 occasions, with serum PTH > $13.5 \mathrm{ng} / \mathrm{L}$ (reference values: 4.5-31.05 ng/L); or 2) albumin-corrected serum calcium $>10.22 \mathrm{mg} / \mathrm{dL}$ on only one occasion with serum PTH > $31.05 \mathrm{ng} / \mathrm{L}(34)$. These values of serum PTH correspond to $20 \mathrm{pg} / \mathrm{mL}$ for assays with 
reference range between 10 to $65 \mathrm{pg} / \mathrm{mL}(34)(\mathbf{B}-2 B)$. Although not all patients selected by these criteria and who have serum PTH levels within the reference range have morphological confirmation, it seems reasonable to consider inappropriately normal serum PTH levels, in the presence of hypercalcemia, as indicative of the diagnosis of PHPT.

The causes of secondary hyperparathyroidism such as the use of thiazide diuretics (35) (C-4) and lithium, vitamin $\mathrm{D}$ deficiency, bisphosphonates, and renal failure, should be excluded (36). Tertiary hyperparathyroidism in renal failure, in addition to genetic causes such as familial hypocalciuric hypercalcemia also need to be excluded. The differential diagnosis with conditions that lead to hypercalcemia should be considered. The finding of a normal corrected serum calcium associated with elevated serum PTH in the absence of other causes help to establish the diagnosis of normocalcemic PHPT (see details below).

Even in the presence of glomerular filtration rates between $40-60 \mathrm{~mL} / \mathrm{min}$, the serum PTH levels may be elevated without being associated with PHPT. Hypercalcemia with very low or undetectable plasma PTH levels is present in malignant diseases in which case PTHrP is often responsible for serum calcium elevation $(33,37)$.

In regard to assays for detection of elevated PTH levels, the second generation ones (measure of intact PTH or "total") measure both the 1-84 primary amino acid sequence of PTH (considered the biologically active full-length moiety), and other large fragments with uncertain biological activity, for example, the truncated PTH (7-84), which besides being found in PHPT, can also be detected in normal persons and accumulate in patients with renal failure (38) (C-4). A so-called third generation or biointact assay that measures only the full length molecule PTH (1-84) was developed to help solve this problem. However, there are few studies comparing the diagnostic sensitivity between the second and third generation assays, some showing the superiority of third generation assays compared to the second (39) and others not (40-42).

Laboratory evaluation should include renal function tests and serum measurement of 25OHD. The 24-hour urinary calcium and the serum creatinine level should be measured. The calcium clearance/creatinine clearance ratio less than 0.01 suggest, but does not prove, familial hypocalciuric hypercalcemia $(22,32)(\mathbf{C}-4)$.

Serum phosphorus levels are usually found to be low in severe disease, and low-normal in milder forms
(42). Specific markers of bone formation (osteocalcin, bone-specific alkaline phosphatase) or bone resorption (deoxypyridinoline, $\mathrm{N}$-telopeptide and C-telopeptide) tend to be in the normal-high range or slightly above the reference values ( 1 ).

Most subjects who present with PHPT are asymptomatic. Reports of overt skeletal involvement with osteitis fibrosa cystica ranges from negligible to as high as $30 \%$. Nephrolithiasis occurs in about $20 \%$ of patients and a neuropsychiatric or neurocognitive component, not necessarily directly linked to PHPT, has been reported in much smaller percentage, about 2\%-3\% (43) (C-4).

A renal ultrasound should be performed if history suggests nephrolithiasis, and can be considered even in the absence of these symptoms to rule out nephrocalcinosis or nephrolithiasis, findings that would argue for surgical intervention (44-46) (B-3B). Bone mineral density (BMD) of the lumbar spine, femur and distal $1 / 3$ radius by dual energy X-ray absorptiometry (DXA) should be evaluated in all patients with PHPT because continuously high PTH exposure has a catabolic effect, mainly at cortical bone (i.e., the distal third radius). Most have involvement of cortical bone with apparent preservation of the trabecular bone by DXA. It is not uncommon to detect skeletal involvement by DXA (osteopenia or osteoporosis) in subjects who do not have radiological features of PHPT $(47,48)($ B-3B).

\section{THE SKELETAL MANIFESTATIONS OF PRIMARY HYPERPARATHYROIDISM}

After the 1970s, when the routine use of serum calcium, as part of a biochemical screening profile, had become common practice, the diagnosis of PHPT on biochemical grounds, increased markedly without evidence for overt skeletal manifestations (49) (C-4). Even at this early stage of the disease, however, asymptomatic PHPT can be associated with high bone turnover $(50,51)(\mathbf{C}-4)$, a reduction in BMD (52) (B2B) and increased fracture risk $(53,55)($ B-2B). After successful parathyroid surgery increased bone remodelling subsides $(51,55)(\mathbf{C}-4)$, BMD increases (55-57) (B-2B) and, with limited data, fracture risk falls (58) (C-4). The amelioration of preoperative findings after parathyroid surgery suggests that the hyperparathyroid state is directly responsible for them.

The prevalence of PHPT and its impact on BMD were evaluated in 3,014 men aged between 69 and 81 years in the Swedish cohort of the MrOs study. Indi- 
viduals with a low glomerular filtration rate $(<21 \mathrm{~mL} /$ $\left.\mathrm{min} / 1.73 \mathrm{~m}^{2}\right)$ and vitamin D deficiency $(<50 \mathrm{nmol} / \mathrm{L})$ were excluded. BMD was compared between patients with and without PHPT. The prevalence of PHPT was estimated at $0.73 \%$. BMD at the total hip and femoral neck was lower in the PHPT group than in the control group. Individuals with inappropriately high intact PTH levels were compared to the rest of the cohort. In that subgroup BMD at the total hip and lumbar spine was lower $(\mathrm{p}<0.05)(52)(\mathbf{B}-2 \mathrm{~B})$. Another subgroup from $\mathrm{Mr}$. Os gave similar results (59).

In a controlled clinical trial, patients with mild PHPT were randomized to parathyroidectomy (PTx) $(\mathrm{n}=25)$ versus non-PTx $(\mathrm{n}=28)$. After 24 months of follow-up, a significant increase in BMD at the femoral neck and total hip was seen, but not at the lumbar spine or forearm in patients undergoing PTx compared with non-PTx patients. There was also a decrease in bone-specific alkaline phosphatise activity after PTx (57) (B-2B). Another study of patients followed for 5 years after PTx, showed a significant increase in lumbar spine BMD, but not hip or distal third of the radius compared to baseline and a decrease in bone turnover markers (55) (C-4).

A case-control study evaluated the rate of vertebral fractures in 150 postmenopausal women with sporadic PHPT and 300 healthy matched controls (53). Vertebral fractures were detected in $24.6 \%$ of patients with PHPT and $4.0 \%$ of controls $(\mathrm{P}<0.0001)$. Most vertebral fractures were mild. To identify if risk factors related to vertebral fractures among patients with PHPT differed from those of control, a logistic regression analysis was performed with variables of age, age at menopause, years since menopause, body mass index, serum total calcium, PTH, 25(OH) vitamin $\mathrm{D}, \mathrm{BMD}$ at the lumbar spine and femoral neck. There was an association of vertebral fractures with BMD at the lumbar spine in patients with PHPT $(\mathrm{P}=0.002)$ and controls $(\mathrm{P}=0.004)$ and with age $(\mathrm{P}=0.04)$ in controls. To examine whether PHPT conveyed an additional risk of vertebral fracture, a logistic regression analysis was performed on the entire sample (patients and controls) using the PHPT status as covariate. Age $(\mathrm{P}=0.015)$ and lumbar spine BMD $(\mathrm{P}=0.01)$ remained associated with vertebral fractures, with a strong correlation of BMD at the lumbar spine and PHPT $(\mathrm{P}<0.0001)$ (53) (B-3B).

A retrospective cohort study evaluated fracturefree survival at 10 years in 533 patients with PHPT.
The initial mean calcium, PTH and serum creatinine were $11.1 \mathrm{mg} / \mathrm{dL}, 116 \mathrm{pg} / \mathrm{mL}$ and $0.9 \mathrm{mg} / \mathrm{dL}$, respectively. PTx was performed in $30 \%$ of patients and $70 \%$ were observed. Fracture-free survival at 10 years after PHPT diagnosis was $94 \%$ in the PTx group and $81 \%$ in the observation group $(\mathrm{p}=0.006)$. Compared with observation, PTx improved fracture-free survival at 10 years by $9.1 \%(\mathrm{p}=0.99), 12 \%(\mathrm{p}=0.92)$ and $12 \%(\mathrm{p}=0.02)$ in patients with $\mathrm{T}$-score $\geq-1.0, \mathrm{~T}$-score between -1.0 and -2.5 , and T-score $<-2.5$, respectively. In multivariate analysis, PTx was independently associated with decreased fracture risk $(\mathrm{HR}=0.41,95 \% \mathrm{CI}$ 0.18-0.93), while non-black patients ( $\mathrm{HR}=2.94,95 \%$ CI 1.04-8.30) and T-score $<-2.5(\mathrm{HR}=2.29,95 \%$ CI 1.08-4.88) remained independently associated with increased fracture risk (58) (C-4).

Studies evaluating different skeleton sites through different methods (three-dimensional analysis of bone biopsy using micro-computerized tomography, conventional two-dimensional bone histomorphometry and quantitative electron imaging) showed differences in the effects of PHPT on the trabecular bone $(33,51,60,61)$.

Conventional two-dimensional bone histomorphometry in patients with PHPT showed thinning and increased cortical porosity, endosteal resorption, and preservation of trabecular bone volume and connectivity (60) (D-5). An analysis of three-dimensional transiliac bone biopsy, using micro-tomography in 29 women with PHPT compared to 20 controls and in 15 men with PHPT, concluded that trabecular bone microarchitecture is preserved in patients with mild PHPT (61) (C-4).

In contrast, a cross-sectional study comparing 36 women with PHPT with 100 healthy controls, quantitative tomography of the radius showed a significant $20 \%$ reduction in volumetric BMD in trabecular bone and a significant reduction of $5 \%$ in the cortical region of interest (5l). In this same group, BMD by DXA densitometry was similar at the lumbar spine, but decreased in the distal third of the radius compared with the controls.

In another study comparing 52 women with PHPT (normocalcemic and hypercalcemic) with 56 controls, peripheral quantitative computed tomography of the tibia showed differences in both trabecular and cortical volumetric BMD, consistent with a catabolic effect on both types of bone in patients with hypercalcemic and normocalcemic PHPT (62) (C-4). 
However, a cohort study of 116 patients with PHPT ( $85 \%$ asymptomatic) followed for 15 years showed that PTx is associated with improved BMD in cortical and trabecular skeletal sites. This study aimed to evaluate BMD during 15 years in patients undergoing or not undergoing PTx. BMD was measured at the lumbar spine, femoral neck and distal radius. In patients who underwent PTx, there was a significant increase in BMD at the 3 sites after 15 years of follow up compared to baseline. In the group not subjected to PTx, BMD did not change in the 3 sites for 8 years and remained stable in the lumbar spine after 15 years of follow up, but $59 \%$ of patients had a $10 \%$ decrease in BMD at one or more locations during the 15 year period (56) (B-2B).

\section{NEUROPSYCHIATRIC MANIFESTATIONS}

Psychiatric symptoms may occur in up to $23 \%$ of patients with PHPT, of which $78 \%$ have depression and anxiety (63). Other manifestations found are fatigue, memory loss, difficulty concentrating, irritability, somatization, mood and sleep disorders $(49,64-66)(\mathbf{C}-4)$.

The prevalence of these abnormalities is not well defined due to the lack of rigorous evaluation of these symptoms in most studies, a small number of studies, and wide variation in the instruments used to assess the psycho-cognitive manifestations (66).

A case-control study that compared 39 postmenopausal patients with mild PHPT with 89 controls showed a higher prevalence of depression and anxiety, in addition to worse performances on tests of verbal and nonverbal memory in women with PHPT (67). In this study, after PTx, there was significant improvement in depressive symptoms, non-verbal abstraction and some aspects of verbal memory (B-3B).
Three randomized clinical studies were conducted to evaluate the effect of PTx versus conservative treatment in patients with mild PHPT on neurocognitive symptoms, among other manifestations $(57,68,69)$ (see details in the "Effects of Parathyroidectomy" section). The data from these studies suggest a significant difference in favor of surgical treatment (A-1A). Furthermore, the association of peripheral neurological disorders, especially sensory-motor polyneuropathy and PHPT, has been suggested by some (Table 3 ) (7076) (C-4).

Some studies have shown that there may be an improvement in neuromuscular symptoms after surgical cure $(70-74,77)$. In a case-control study that evaluated 9 patients with PHPT and neuromuscular disorders, there was improvement in strength and fine motor movement four weeks after PTx in all patients with PHPT, which did not occur in the control group who underwent surgical treatment for benign thyroid disease (77) (B-3B). Future research is clearly needed to better understanding of central and peripheral nervous system involvement in PHPT (78).

\section{CARDIOVASCULAR MANIFESTATIONS}

Some studies have shown variable prevalence rates of cardiovascular abnormalities in patients with PHPT with variable degree of increased morbidity (79) and mortality as well (80-82) (C-4). These include arterial hypertension (83-85) (C-4), left ventricular hypertrophy (86-88) (C-4), cardiac function abnormality $(86,89)(\mathbf{C}-4)$, coronary artery disease $(90)(\mathbf{C}-4)$, vascular abnormalities (91-94) (C-4), conduction disturbances $(95)(\mathbf{C}-4)$ and valvular and myocardial calcification (96) (C-4). Lipid abnormalities with a decrease

Table 3. Case reports of peripheral neuropathy related to primary hyperparathyroidism

\begin{tabular}{|c|c|c|c|c|c|c|}
\hline Author & Gender & $\begin{array}{c}\text { Age } \\
\text { (years) }\end{array}$ & $\begin{array}{c}\text { Other cause of } \\
\text { neuropathy }\end{array}$ & Type of neuropathy & $\begin{array}{l}\text { Histopathological } \\
\text { findings }\end{array}$ & $\begin{array}{c}\text { Resolution after } \\
\text { parathyroidectomy }\end{array}$ \\
\hline Conri and cols. (70) & $\mathrm{F}^{1}$ & 34 & Hypoglycemia & Motor polyneuropathy & $\begin{array}{c}\text { Muscle atrophy, } \\
\text { nonspecific acute axonal } \\
\text { injury }\end{array}$ & Yes \\
\hline Moskal (72) & $\mathrm{M}^{2}$ & 63 & Neoplasia & $\begin{array}{l}\text { Sensorimotor } \\
\text { polyneuropathy }\end{array}$ & $\mathrm{NR}^{3}$ & $\mathrm{NR}^{3}$ \\
\hline Logullo and cols. (73) & $\mathrm{M}^{2}$ & 71 & No & $\begin{array}{l}\text { Sensorimotor } \\
\text { polyneuropathy }\end{array}$ & $\mathrm{NR}^{3}$ & Yes \\
\hline Olukoga (74) & $\mathrm{F}^{1}$ & 65 & No & $\begin{array}{l}\text { Sensorimotor } \\
\text { polyneuropathy }\end{array}$ & $\mathrm{NR}^{3}$ & Yes \\
\hline Eufrazino and cols. (71) & $\mathrm{F} 1 / \mathrm{M}^{2}$ & $51 / 76$ & No & Sensory polyneuropathy & $\mathrm{NR}^{3}$ & Yes \\
\hline
\end{tabular}

${ }^{1} \mathrm{~F}$ : female; ${ }^{2} \mathrm{M}$ : male; ${ }^{3} \mathrm{NR}$ : not reported. 
in serum HDL-C and increase in triglycerides have also being described $(79,97)(\mathbf{C}-4)$.

There are few controlled studies on arterial hypertension and PHPT, which is the reason why it is unclear whether left ventricular hypertrophy and diastolic dysfunction, when present, are secondary effects of hypertension or directly caused by PTH and elevated serum calcium $(91,98)$. The presence of PHPT was a stronger positive predictor of a higher rate of arterial resistance than age, sex, smoking, dyslipidemia, hypertension and diabetes mellitus, according to a study conducted at Columbia University, NY. The pulse wave analysis showed a higher rate of arterial resistance in patients with PHPT $(28 \pm 10$ vs. $25 \pm 10 \%)$ but without statistical significance (91) (C-4). Another case-control study evaluated left ventricular (LV) size, diastolic dysfunction and valvular calcification in patients with mild PHPT. After adjustment for potential confounders, no association between high levels of $\mathrm{PTH}$, serum calcium or vitamin $\mathrm{D}$ deficiency with left ventricular hypertrophy or myocardial and mitral annular calcification was observed. These manifestations were present only in the more severe forms of the disease, or in the presence of arterial hypertension and other risk factors (99) (B3B). Data on the effects of PTx on those outcomes are still conflicting $(85,100,101)(\mathbf{C}-4)$.

Although the published literature about cardiovascular consequences of PHPT is conflicting due to small sample size and/or low statistical power of most studies, more recent population studies have suggested that a milder form of the disease may be associated with increased all-cause mortality and an increase of fatal and nonfatal cardiovascular disease $(65,102)(\mathrm{B}-2 \mathrm{~B})$.

\section{NORMOCALCEMIC PRIMARY HYPERPARATHYROIDISM}

Patients undergoing routine assessment or during an investigation of bone loss may present with increased serum PTH levels in the absence of hypercalcemia $(49,103)$. The term normocalcemic primary hyperparathyroidism (NPHPT) was initially used in 1960 with a report of a group of patients with different characteristics from those diagnosed with classic PHPT (104). The patients had normal serum calcium levels in the presence of high PTH levels $(47,104)(\mathbf{B}-2 B)$. Nowadays, however, with the widespread availability of PTH assays and their use in the work up in individuals who are referred for syndromes of low bone mass, the con- dition has gained increased attention by the scientific community (105).

In order to establish, with reasonable certainty, the diagnosis of NPHPT, it is mandatory to search for causes of secondary hyperparathyroidism (Table 4), particularly vitamin D deficiency $(36,106)($ B-2B).

Table 4. Causes of secondary hyperparathyroidism

Chronic kidney disease (GFR $\left.{ }^{*}<60 \mathrm{ml} / \mathrm{min}\right)$

Medications (bisphosphonates, anticonvulsants, hydrochlorothiazide ${ }^{\star *}$, denosumab, furosemide, phosphorus)

Renal hypercalciuria

Malabsorption syndrome (celiac disease, cystic fibrosis)

$25-\mathrm{OH}$ vitamin D deficiency ( $<50 \mathrm{nmol} / \mathrm{L}$ or $20 \mathrm{ng} / \mathrm{mL}$ )

Pseudohypoparathyroidism type 1

*GRF: glomerular filtration rate; ** Ref.: 106.

It remains uncertain whether NPHPT represents an incipient form of classic PHPT or a different spectrum of this condition (47). Follow-up should include periodic measurement of the, serum calcium concentration $(105,106)(B-2 B)$.

If NPHPT is an incipient form of classic PHPT with hypercalcemia, the serum calcium would be expected to increase over time. A prospective study involving 41 patients showed that approximately $20 \%$ of patients developed hypercalcemia over a 3 -year period. In addition, $40 \%$ of normocalcemic patients showed disease progression by nephrolithiasis, hypercalciuria, bone loss and fractures, even though the serum calcium did not necessary increase. PTx showed clear-cut evidence for parathyroid disease (104) (C-4).

It is important to note that the cohorts of NPHPT that have been described so far have come from referral centers. As such, these individuals often demonstrate evidence for skeletal disease. It remains to be seen whether a different phenotype of NPHPT, as well as normocalcemic or subclinical hypoparathyroidism, would be discovered if community dwelling subjects, without referral bias, were to be screened $(59,107)$.

Some other studies have also suggested that NPHPT is not an indolent condition. A retrospective case series study compared the clinical and laboratory data of patients with mild hypercalcemic PHPT $(\mathrm{n}=37)$ with patients with NPHPT $(\mathrm{n}=33)$. The frequency of nephrolithiasis was similar between the two groups $(18.9 \% \mathrm{vs}$. $18.2 \%, \mathrm{p}=0.937)(46)$. This was also observed when NPHPT patients were compared with non-PHPT controls (47) (C-4). 


\section{IMAGING PROCEDURES AND LOCALIZATION TECHNIQUES}

Ultrasonography of the anterior neck is widely used to locate the parathyroid lesion. While inexpensive and non-invasive, it has the disadvantages of limited resolving power and being operator-dependent (108). Moreover, with ectopically located parathyroid glands, particularly intrathyroidal parathyroid adenoma, it can be difficult to differentiate them from thyroid nodules (Table 5). Ultrasonography has a sensitivity of $88 \%$ and specificity of $94 \%$ but when combined with Tc$-99 \mathrm{~m}$ Sestamibi scan by SPECT-CT, the sensitivity and specificity may rise to 97 and 100\%, respectively (109) (C-4).

Table 5. Parathyroid localization techniques

Cervical ultrasonography

Computed tomography

Magnetic resonance imaging

Tc-99m sestamibi scintigraphy

PTH measurement in nodule aspiration fluid (FNA*)

${ }^{*}$ FNA: fine needle aspiration.

Tc-99m uptake in the sestamibi scan depends on the size and weight of parathyroid lesion. In a study of 64 patients with various degrees of severity of PHPT, Tc$99 \mathrm{~m}$ Sestamibi showed positive results in $64 \%$ of patients with asymptomatic PHPT, $83 \%$ in the group with nephrolithiasis without bone involvement and $100 \%$ in those with severe disease characterized by osteitis fibrosa cystica; of those, $70 \%$ showed increased uptake on the initial images, whereas in the other groups, increased uptake was seen only on the delayed images (110) (C-4). In a prospective cohort study with 487 patients, the positive Sestamibi scan was associated with higher rates of biochemical cure than those with a negative test $(97 \%$ vs. $89 \%$, respectively; $\mathrm{p}=0.008)(111)(\mathrm{B}-2 \mathrm{~B})$.

The four-dimensional computed tomography permits locating abnormal parathyroid tissue (adenomatous or hyperplastic) with high accuracy as compared to ultrasonographic and scintigraphic techniques. In a retrospective study of 35 cases of histologically confirmed PHPT, 4D-CT demonstrated a sensitivity of 91\% (32 positive cases). The method successfully located a single affected gland with $93 \%$ accuracy. In the assessment of multiglandular disease, however, sensitivity fell to $44 \%$ but specificity was impressively, at $100 \%$ (112). Preoperative localization of abnormal parathyroid tissue permits less aggressive surgical techniques such as minimally invasive parathyroidectomy (MIP), which can be performed as a same-day procedure, reducing patient morbidity and costs (112) (C-4).

A study performed in our institution showed that Sestamibi imaging may also detect brown tumors in severe PHPT(113). This abnormal uptake is still not well explained, but seems to be due to increased osteoclastic activity and perfusion of the lesion. In the presence of metastatic disease the differential diagnosis between benign and malignant disease can be difficult (113).

Sestamibi scanning may show false-positive results in the presence of thyroid nodules and false negatives, due to the size and location of the affected parathyroid lesion. In this situation, fine needle aspiration and measurement of PTH in the aspirated fluid may indicated (114). A comparative study between a group of 15 women with PHPT and 15 women without PHPT who had nodules visualized by ultrasound, found very high PTH values with a mean of $4,919 \mathrm{pg} / \mathrm{mL}$ in PHPT patients compared to $10.65 \mathrm{pg} / \mathrm{mL}$ in controls $(114)(\mathbf{C}-4)$.

\section{INDICATIONS FOR PARATHYROIDECTOMY}

PTx is the treatment of choice for all patients with symptomatic PHPT. Various studies $(115,116)$ have demonstrated regression of skeletal abnormalities such as an increase in BMD and in severe cases, reduction of osteoclastomas (C-4). Biochemical aspects of the disease return to normal promptly. According to the Third International Workshop, surgery should also be recommended for asymptomatic patients, if a criterion for surgery is met (78). In asymptomatic PHPT, surgery is recommended if patients meet one or more of the following criteria: (Table 6) (D): 1. T-score $<-2.5$ at any site (lumbar spine, hip, or distal $1 / 3$ forearm) or history of fragility fracture $(68) ; 2$. Age $<50 ; 3$. Creatinine clearance $<60 \mathrm{~mL} / \mathrm{min} / 1.73 \mathrm{~m}^{2} ; 4$. Serum calcium concentration $>1 \mathrm{mg} / \mathrm{dL}$ above the laboratory reference value. Ideally, this criterion should be met by measurement of 3 albumin-corrected calcium values in the fasting state. Any drugs that could theoretically interfere with the calcium measurement (i.e., lithium or thiazide diuretics) should be stopped at least 4-6 weeks in advance (117).

The workshop also pointed out that parathyroid surgery in asymptomatic patients who do not meet surgical guidelines is not an inappropriate course if there is consensus among the endocrinologist, the parathyroid surgeon and the patient, and there are no medical contraindications to parathyroid surgery. 
Table 6. Indications for surgery in asymptomatic primary hyperparathyroidism treatment according to the NIH Third International Workshop

1 - Serum calcium $>1 \mathrm{mg} / \mathrm{dL}$ above ULN*

2 - Creatinine clearance $<60 \mathrm{~mL} / \mathrm{min} / 1.73 \mathrm{~m}^{2}$

$3-$ T-score $<-2.5$ at the lumbar spine, hip and/or distal radius or previous fragility fracture

$4-$ Age $<50$ years

5 - Patients whose medical monitoring is not possible

* ULN: upper limit of normal. Adapted from Ref. 78.

Considering the minimal significant changes in the rate of bone loss during the natural evolution of the disease $(78,118)$, other asymptomatic PHPT patients who do not meet criteria for surgery or who have a contraindication, should be followed with regular BMD monitoring. Patients with vitamin D deficiency (serum $25-\mathrm{OHD}<20 \mathrm{ng} / \mathrm{mL}$ ) should receive adequate replacement, following the recommendations for patients without PHPT (78).

Randomized studies $(57,68,69)$, but with limited follow-up time ( $1-3$ years) have demonstrated benefits in quality of life and BMD in asymptomatic patients who undergo surgery (A-1B).

These guidelines from the Third International Workshop are not rules. The decision for or against parathyroid surgery should be made individually, based upon each affected patient, the physician's judgement, and the experience and availability of an experienced parathyroid surgeon.

Cure rates with resection of the affected glands are 95\% to $98 \%$ in the hands of experienced parathyroid surgeons. Complications such as bleeding, postoperative hypocalcemia and recurrent laryngeal nerve injury are very unusual (1\%-3\%). The MIP technique may be associated with lower morbidity and costs (119) (B-3B).

\section{SURGICAL PROCEDURES}

The surgeon's experience, in large part, determines cure and complication rates of PTx (C-4) $(120,121)$. Neck exploration with direct visualization and identification of all abnormal parathyroid glands, with their subsequent removal, is the gold standard in the surgical treatment of PHPT (30).

A retrospective study of 1,112 patients, over a period of 17 years, evaluated the cure rate, complications and operative time of PTx with bilateral neck exploration. The cure and complication rates were $97.4 \%$ and
$3.4 \%$, respectively. Recurrent laryngeal nerve injury was seen in $0.2 \%$ of cases, postoperative bleeding in $0.8 \%$ and transient hypocalcemia in $1.8 \%$. There was no excess mortality. The mean operative time was $52.5 \pm$ 30.2 minutes (108) (C-4).

Recent techniques, including improved preoperative localization techniques, with or without intraoperative PTH measurement, endoscopic refinement and intraoperative gamma probe use have all resulted in the widespread application of minimally invasive surgery (122).

MIP encompasses a number of different techniques such as: open approaches (open minimally-invasive parathyroidectomy - OMIP) (123), minimally-invasive radio-guided parathyroidectomy (MI-RP) (124), video-assisted parathyroidectomy (MIVAP) $(125,126)$, and purely endoscopic parathyroidectomy (EP) (127).

A prospective, randomized study of 60 individuals with concordant localization of a parathyroid adenoma by ultrasonography and technetium-99m sestamibi scintigraphy, who were eligible for MIP, were randomized into two groups: MIVAP and OMIP. Patients undergoing MIVAP vs. OMIP had similar operative time $(\mathrm{P}=0.22)$ and rates of transient hypocalcemia $(\mathrm{P}$ $=1.0)$; less pain $4,8,12$, and 24 hours after surgery $(\mathrm{P}<0.001)$, less analgesia requirement $(\mathrm{P}=0.01)$, better physical functioning and quality of life in the early postoperative period $(\mathrm{P}=0.02$ and $\mathrm{P}=0.003$, respectively). Shorter scar length $(\mathrm{P}<0.001)$ and greater aesthetic satisfaction were observed 1 month after surgery $(\mathrm{P}=0.006)$, but there were no significant differences 6 months post-surgery. MIVAP was more expensive $(\mathrm{P}<0.001)$, while the average hospital stay was simi$\operatorname{lar}(\mathrm{P}=0.22)$. Differences between serum calcium and PTH during 6 months of follow-up were not significant (126) (B-2B).

There is also some evidence that MIVAP has some advantages over other purely endoscopic procedures and video-assisted parathyroidectomy through a lateral approach (VAP-LA), in terms of bilateral exploration and associated procedures on the thyroid gland (128) (C-4).

There are few prospective, well-designed studies, comparing conventional PTx and minimally invasive exploration despite showing no differences in cure or complication rates when performed by experienced surgeons (129-131) (B-2B). There may be differences when operative time and costs are considered $(129,132,133)($ A-1B). 
A prospective randomized study compared MIP to conventional PTx in 48 patients with PHPT. In the group with bilateral neck exploration, neither preoperative imaging nor intraoperative PTH measurements were performed. Patients in both groups had similar cure rates and operative times. In the group undergoing MIP there was less pain 4, 8, 16, 24, 36 and 48 hours postoperatively $(\mathrm{p}<0.001)$, lower analgesic consumption $(\mathrm{p}<0001)$, lower analgesia requirement $(\mathrm{p}<$ $0.001)$, less scarring $(\mathrm{p}<0.001)$ and greater aesthetic satisfaction 2 days, 1 month $(\mathrm{p}<0.01)$ and 6 months after surgery $(<0.05)$, but after 1 year the aesthetic satisfaction became non-significant $(\mathrm{p}=0.38)$. MIP was more costly and there was no difference in the quality of life in both groups 1 month and 6 months after surgery (133) (A-1B) (Table 7).

Table 7. Advantages of minimally invasive parathyroidectomy

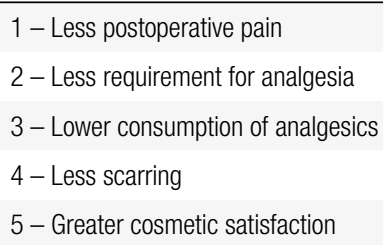

Another randomized, prospective study on 45 patients who underwent conventional PTx or MIP, showed similar cure rates for both procedures within 6 months of follow-up. The operative time was $22 \mathrm{~min}$ utes shorter in patients undergoing MIP and serum calcium levels were slightly lower in the first 4 postoperative days in the group that underwent bilateral neck exploration (129) (B-2B).

\section{BENEFITS OF PARATHYROIDECTOMY}

PTx is a definitive therapy for PHPT which may provide, in addition to biochemical cure, reduced risk of nephrolithiasis, improved BMD, decreased risk of fractures and improved quality of life (134).

\section{Bone mineral density}

Asymptomatic patients undergoing surgery have an increase in BMD that is $>10 \%$ during the first decade $(135)$ (B-2B). Symptomatic patients with severe bone involvement may have greater increases of as much as 60 to $100 \%$ in the first post-operative year (2) (B-3B). After 15 years of PTx, the gain in BMD remains stable in the lumbar spine, femoral neck and distal radius (56) (B-2B). In a small case-control study, an $8 \%$ increase in cortical bone thickness and area was observed, in addition to an increase in volumetric BMD, 1 year after $\operatorname{PTx}(136)(\mathbf{B}-3 B)$.

Some randomized clinical trials have demonstrated an increase in BMD after PTx $(68,69,137)$ (Table 8 ). In one study, after 2 years of surgical treatment, there was a significant increase in lumbar spine BMD in the surgically treated group, when compared with conservative treatment, in which BMD remained unchanged $(1.01 \pm 0.18 v$ vs. $1.13 \pm 0.19, \mathrm{p}<0.01)(68)$ (A-1B). Another randomized study showed that after 2 years of surgery, modest improvement in femoral neck bone density (a difference between the groups of $0.8 \%$ per year, $\mathrm{P}=0.01$ ) and total hip (difference between groups of $1.0 \%$ per year, $\mathrm{P}=0.001$ ) in the group that underwent PTx, compared to the conservative treatment group (57) (A-2B).

Observational studies have also demonstrated significant improvement in BMD after PTx $(114,135,138,139)$. In a prospective cohort of 121 patients with PHPT followed for 10 years, there was an increase of $12 \%$ to $15 \%$ in BMD of patients undergoing PTx (135), especially in the lumbar spine and hip (B-2B).

In a 15 year follow-up of the same cohort that did not undergo PTx, there was a $10 \%$ decrease in cortical bone in the femoral neck and $35 \%$ in the distal radius (56) (B-2B). Most of the bone loss occurred after the first 8 years of follow-up. Most studies (135,138-143), but not all $(143,144)$ do not show reduction in BMD at any sites during the first years of observation without intervention (B-2B).

\section{Fracture risk}

Despite a small study suggesting that mild PHPT does not increase the risk of vertebral fracture (145) (B2B), observational cohort and case-control studies suggest that there may be an increased risk of vertebral and nonvertebral fractures $(53,54,146,147)$ (B2B). There are no data available yet from randomized clinical studies evaluating fracture risk reduction after PTxs. However, observational studies suggest a benefit for the group that underwent intervention $(146,147)($ B-2B $)$.

\section{Neuropsychiatric symptoms}

In some situations, PTx appears to improve some neuropsychiatric parameters, such as cognition, mood, anxiety $(148,149)(\mathbf{C}-4)$, quality of life and psychological function $(57,68)(B-2 B)$. 
Table 8. Results of randomized trials on the effects 1 year after PTx on BMD and neuropsychiatric symptoms in patients with PHPT

\begin{tabular}{|c|c|c|c|c|c|c|c|c|c|c|c|c|}
\hline & \multirow{2}{*}{$\begin{array}{c}\text { N (PTx) } \\
-\end{array}$} & \multicolumn{2}{|c|}{ sCA (mg/dL) } & \multirow{2}{*}{$\begin{array}{l}P \\
-\end{array}$} & \multicolumn{2}{|c|}{ sPTH $(p g / m L)$} & \multirow{2}{*}{$\begin{array}{l}P \\
-\end{array}$} & \multirow{2}{*}{\multicolumn{2}{|c|}{$\frac{\text { BMD }\left(\mathrm{g} / \mathrm{cm}^{2}\right)}{\text { Observation x PTx }}$}} & \multirow{2}{*}{$\begin{array}{l}P \\
-\end{array}$} & \multirow{2}{*}{$\begin{array}{c}\text { SF-36 } \\
\begin{array}{c}\text { Observation x } \\
\text { PTx }\end{array}\end{array}$} & \multirow{2}{*}{$\begin{array}{l}P \\
-\end{array}$} \\
\hline & & Before PTx & After PTx & & Before PTx & After PTx & & & & & & \\
\hline $\begin{array}{l}\text { Rao and } \\
\text { cols. (57) }\end{array}$ & 25 & $10.41 \pm 0.5$ & $9.33 \pm 0.42$ & $<0.001$ & $87 \pm 27$ & $39 \pm 28$ & $<0.001$ & $\begin{array}{r}\uparrow 1.2 \% \\
\uparrow 0.4 \% \\
\uparrow 0.4 \%\end{array}$ & $\begin{array}{l}\text { (spine) } \\
\text { (femur) } \\
\text { forearm) }\end{array}$ & $\begin{array}{c}<0.001 \\
0.03<0.001\end{array}$ & $\begin{array}{l}\text { Improvement in } \\
\text { social } \\
\text { functioning } \\
\text { Improvement in } \\
\text { emotional } \\
\text { functioning }\end{array}$ & $\begin{array}{l}<0.007 \\
<0.012\end{array}$ \\
\hline $\begin{array}{l}\text { Ambrogini } \\
\text { and cols. } \\
\text { (69) }\end{array}$ & 24 & NR & NR & NR & NR & NR & NR & $\begin{array}{r}\uparrow 6.5 \% \text { (t } \\
\uparrow 5.3 \% \\
\uparrow 4.5 \% \\
\uparrow 4.4 \% \text { ffer }\end{array}$ & $\begin{array}{l}\text { ochanter) } \\
\text { (spine) } \\
\text { (hip) } \\
\text { noral neck) }\end{array}$ & $\begin{array}{c}0.0001 \\
0.0002 \\
0.0001 \\
0.01\end{array}$ & $\begin{array}{l}\text { Improves pain } \\
\text { Improves } \\
\text { general health } \\
\text { Improves vitality } \\
\text { Improves } \\
\text { mental health }\end{array}$ & $\begin{array}{c}0.001 \\
0.08 \\
\\
0.003 \\
0.017\end{array}$ \\
\hline $\begin{array}{l}\text { Bollerslev } \\
\text { and cols. } \\
\text { (68) }\end{array}$ & 60 & $10.7 \pm 0.32$ & $9.9 \pm 0.56$ & $<0.001$ & $107.5 \pm 58.3$ & $44.9 \pm 20.4$ & $<0.001$ & $\begin{array}{l}\text { Observation } \\
1.04 \pm 0.20\end{array}$ & $\begin{array}{c}\text { PTx } \\
1.13 \pm 0.19\end{array}$ & $<0.05$ & $\begin{array}{l}\text { Improvement in } \\
\text { social } \\
\text { functioning } \\
\text { Improvement in } \\
\text { emotional } \\
\text { functioning }\end{array}$ & $\begin{array}{l}<0.05 \\
<0.05\end{array}$ \\
\hline
\end{tabular}

PTX: parathyroidectomy; BMD: bone mineral density; PHPT: primary hyperparathyroidism; sCA: serum calcium; sPTH: serum parathyroid hormone; NR: not-related; SF-36: Quality Questionnaire "Short Form-36 Health Survey".

Most published studies are observational and, thus, have important limitations, such as selection bias, lack of uniform methods for description of neurological and psychiatric symptoms, presence of symptomatic patients with PHPT and inadequate control groups. Ideally, randomized long-term studies are needed to determine the actual benefit of PTx for such symptoms. However, one of the difficulties lies in the recruitment of asymptomatic patients who agree to undergo randomization for surgical treatment $(150,151)$.

Despite these limitations, some randomized studies have demonstrated a benefit of Ptx on neuropsychiatric symptoms in patients with asymptomatic PHPT $(57,69,137)$ (Table 8$)$.

In a study from Norway, 191 patients (mean calcium, $10.8 \mathrm{mg} / \mathrm{dL}$ ) were randomized to surgical or conservative groups (68). At baseline, all patients had low psychosocial (quality of life) and mental health rates, as assessed by questionnaires "Short Form-36 Health Survey" (SF-36) and "Comprehensive Psychopathological Rating Scale", respectively. There were no significant improvements in these parameters in the surgically treated group compared to the control group. There was only a small difference in physical and emotional symptoms in the surgery group (68) (A-1B).

In another study, among 283 patients selected, 53 agreed to participate in the randomization (mean serum calcium $10.3 \mathrm{mg} / \mathrm{dL}$ ) for conservative or surgical treatment. At baseline, the "Short Form-36 (SF-36) Health Survey" mean score was similar to the normal population. Those who underwent the conventional surgical treatment showed little change in psychosocial function after 2 years, despite a significant decline in the conservative group. After 42 months of follow-up, there was a significant benefit of surgery in 2 domains of the SF-36 scale (social functioning and emotional problems) (57) (A-1B).

Another study randomized 50 patients, with mean serum calcium of $10.2 \mathrm{mg} / \mathrm{dL}$, for surgical or conservative treatment. There were modest improvements in some quality of life parameters in SF-36 of patients undergoing surgical treatment, among them, generalized pain, vitality, general health and mental health (69) (A-1B).

\section{Cardiovascular risk}

In some studies, Ptx has shown some benefit in cardiovascular parameters such as blood pressure, left ventricular diastolic function and left ventricular mass index $(152,153)$. Other studies, however, do not confirm these findings $(100,150,154,155)(\mathbf{B}-3 \mathbf{B})$.

Some cohort studies demonstrate improved survival after PTx (146,152), which was not confirmed by a more recent study that provided long-term follow up (153) (B-2B).

Few randomized controlled trials have evaluated the cardiovascular benefits of surgical treatment in asymptomatic PHPT. In a study on 116 patients, comparing conservative treatment versus $\mathrm{PTx}$, the mean reduction in blood pressure did not differ significantly between groups, as well as the serum levels of adiponectin, lip- 
ids, leptin, C-reactive protein and markers of endothelial dysfunction, such as von Willebrand factor (116) (B-3B).

In an observational study, surgical treatment was associated with improvement of left ventricular hypertrophy in patients without previous hypertension (89) (B-3B). However, most other observational studies indicate that hypertension does not improve significantly after PTx and should not be considered an indication for surgical treatment $(64,154)(\mathbf{B}-3 \mathbf{B})$ (Table 9).

\section{THE ROLE OF INTRAOPERATIVE SERUM PTH MEASUREMENTS}

Intraoperative monitoring of serum PTH (IOPTH) is often used during MIP for PHPT. Serum PTH is measured after induction of anesthesia but prior to skin incision and 10 minutes after removal of the enlarged gland (156). If the postoperative PTH levels does not fall by $>50 \%$, into the normal range, persistent disease must be suspected. In the Ohe and cols. study on $109 \mathrm{pa}-$ tients (33 with PHPT and 76 with hyperparathyroidism secondary to renal disease) IOPTH changes correlated with cure of the disease (157) (C-4). Despite the widespread use of the IOPTH approach, some studies have suggested its use only in selected patients (158) (C-4). A prospective study of 361 patients undergoing MIP for PHPT aimed to determine whether IOPTH can be optimized by limiting its application to patients with non-conclusive preoperative localization. All patients underwent technetium-99m sestamibi scintigraphy and ultrasonography. IOPTH was only used for decision-making in patients with negative scintigraphy and positive ultrasound results. Patients with any positive locali- zation procedure (91\%) were offered MIP. The success rate was $99 \%$. The multiglandular disease rate was $3 \%$ in sestamibi-positive and $36 \%$ by sestamibi-negative ( $\mathrm{p}$ $<0.0001$ ). Both ultrasound and sestamibi scintigraphy had the same sensitivity $(80 \% \times 85 \%)$. Among patients with negative sestamibi, $71 \%$ of those who underwent MIP with IOPTH, had an inadequate fall in PTH levels and this was highly predictive of multiglandular disease. The use of IOPTH increased the time length of surgery from 34 to 60 minutes (159) (C-4).

Barczynski and cols., in a comparative, retrospective non-randomized study, found that the routine use of IOPTH improved MIP cure rates (open or video-assisted) compared to unilateral neck exploration guided by imaging without IOPTH. Furthermore, IOPTH had an additional value in the surgical decision for future neck exploration, especially in the case of a single positive imaging study (158) (C-4).

In a large multicenter study from Scandinavian on 2,708 patients, imaging procedures for preoperative localization were performed in 1,831 patients (sestamibi scan in $54 \%$ and ultrasonography in $41 \%$ ) and IOPTH in 792 patients. Bilateral exploration was performed in $61 \%$, focused PTx in $17 \%$ and unilateral exploration in $22 \%$. In a multivariate logistic regression analysis, IOPTH increased cure rate (OR 1.70, CI 95\% 1.14-2.53, $\mathrm{p}=$ 0.0092 ). The risk of hypocalcemia decreased with the use of localization procedures (OR $0.56,95 \%$ CI 0.43 $0.78, \mathrm{p}=0.0004)$ and IOPTH (OR $0.5695 \%$ CI 0.39 $0.90, \mathrm{p}=0.0015)(160)(\mathrm{B}-2 \mathrm{C})$. On the other hand, a prospective randomized trial comparing endoscopic bilateral neck exploration with endoscopic MIP plus IOPTH, found no differences in effectiveness, operation time and costs between the procedures (161) (B-2B).

Table 9. Results of studies on the effects of PTx on blood pressure (BP) and left ventricular (LV) hypertrophy in patients with PHTP

\begin{tabular}{|c|c|c|c|c|c|c|c|c|c|c|c|}
\hline & \multirow{2}{*}{$\begin{array}{c}\mathrm{N} \\
\text { (PTx) }\end{array}$} & \multicolumn{2}{|c|}{$\begin{array}{c}\text { sCA } \\
(\mathrm{mM} / \mathrm{L})^{\star \star}\end{array}$} & \multirow{2}{*}{$P$} & \multicolumn{2}{|c|}{ sPTH } & \multirow{2}{*}{$P$} & \multirow{2}{*}{$\begin{array}{c}\text { Change BP } \\
(\mathrm{mmHg})\end{array}$} & \multirow{2}{*}{$P$} & \multirow{2}{*}{$\begin{array}{l}\text { Changes in } \\
\text { cardiac } \\
\text { structure } \\
\text { (LVH) }\end{array}$} & \multirow{2}{*}{$P$} \\
\hline & & Before PTx & After PTx & & Before PTx & After PTx & & & & & \\
\hline $\begin{array}{l}\text { Persson and } \\
\text { cols. (153) } \\
\text { Randomized }\end{array}$ & 49 & $2.67 \pm 0.06$ & 2.4 & $<0.01$ & $\begin{array}{c}11.08 \pm 3.87 \\
(\mathrm{pmol} / \mathrm{L})\end{array}$ & $5.0(\mathrm{pmol} / \mathrm{L})$ & $<0.01$ & No change & NS & $\begin{array}{c}\text { Reduction of LV } \\
\text { mass }\end{array}$ & NS \\
\hline $\begin{array}{l}\text { Farahnak and } \\
\text { cols. (154) } \\
\text { Case control }\end{array}$ & 51 & $2.62 \pm 0.13$ & $2.28 \pm 0.08$ & $<0.001$ & $\begin{array}{c}122.6 \pm 43.6 \\
(\mathrm{pg} / \mathrm{mL})\end{array}$ & $\begin{array}{c}48.8 \pm 15.9 \\
(\mathrm{pg} / \mathrm{mL})\end{array}$ & $<0.001$ & Decreased & $<0.05$ & NS & NS \\
\hline $\begin{array}{l}\text { Bollerslev and } \\
\text { cols. (116) } \\
\text { Randomized }\end{array}$ & 116 & $2.69 \pm 0.11$ & 2.4 & $<0.01$ & $\begin{array}{c}10.1 \pm 4.0 \\
(\mathrm{pmol} / \mathrm{L})\end{array}$ & $\begin{array}{c}5.0 \\
(\mathrm{pmol} / \mathrm{L})\end{array}$ & $<0.01$ & Decreased & $<0.05$ & NR & NR \\
\hline $\begin{array}{l}\text { Ishay and cols. } \\
(100) \\
\text { Case control }\end{array}$ & 34 & $11.2 \pm 0.7^{\star}$ & NR & - & $\begin{array}{c}222.9 \pm 189.8 \\
(p g / m L)\end{array}$ & NR & - & Decreased & 0.02 & NR & NR \\
\hline
\end{tabular}

* In mg/dl; ** in mmol/L; NR: not reported; NS: non-significant; PTx: parathyroidectomy; PHTP: primary hyperparathyroidism; sCA: serum calcium; sPTH: serum parathyroid hormone. 


\section{MEDICAL TREATMENT}

Pharmacological treatment can be indicated for those patients with contraindications to surgical treatment, those with surgical failure, or those with no current criteria for surgical treatment $(162,163)$ (Table 10). The decision to employ a pharmacological approach depends also upon the goal of treatment, to reduce the serum calcium level and/or to increase BMD.

\section{Cinacalcet hydrochloride}

Cinacalcet hydrochloride is a calcimimetic agent that binds to the calcium-sensing receptor $(\mathrm{CaR})$ of parathyroid cells, resulting in diminished PTH secretion (163). A multicenter, randomized, double-blind, placebo-controlled study on 78 patients with PHPT, evaluated the long-term effect of oral cinacalcet on serum calcium and PTH levels. The primary endpoint was the normalization of serum calcium $(<10.3 \mathrm{mg} / \mathrm{dL})$ with a reduction of at least $0.5 \mathrm{mg} / \mathrm{dL}$ from baseline. Patients initially received cinacalcet $30 \mathrm{mg}$ twice daily and this dose was increased to $40-50 \mathrm{mg}$ twice daily for 12 weeks. Normal serum calcium concentrations were achieved in $73 \%$ of patients during the maintenance phase, but serum PTH decreased by only $7.6 \%$ after the same period (164). Serum calcium levels remained normal and PTH remained below baseline for up to 52 weeks (A-1B). The extension of the same study for 5 years showed that the normalization of serum calcium levels was maintained in approximately $80 \%$ of patients. Mean serum PTH levels remained stable (165). There were no significant changes in BMD. Oddly, bone turnover markers (serum bone alkaline phosphatase and urinary $\mathrm{N}$-telopeptide) increased significantly as compared to placebo (164) (A-1B).

Cinacalcet is generally well-tolerated. The most common side effects are nausea $(28 \%)$ and headache $(23 \%)(164,166)(A-1 B)$. These side effects appear to be dose-dependent.

\section{Hormone replacement therapy}

A 2-year, randomized, double-blind, placebo-controlled study on 42 postmenopausal women with mild
PHPT, evaluated the effects of conjugated estrogen $0.625 \mathrm{mg} /$ day combined with medroxyprogesterone $5 \mathrm{mg} /$ day versus placebo on BMD and biochemical markers of bone turnover and calcium metabolism. Alkaline phosphatase activity decreased by $22 \%$, urinary hydroxyproline excretion by $38 \%, \mathrm{~N}$-telopeptide excretion decreased by $60 \%$ and urinary calcium excretion by $33 \%$ at the end of the study (144). Likewise, there were significant increases in total body, lumbar spine, femur neck and forearm BMD (144) (A-1B). These effects were maintained for at least 4 years in the extension study (167) (B-2B).

\section{Selective modulators of estrogen receptors}

A small study of only 18 patients tested raloxifene 60 $\mathrm{mg} /$ day to reduce the serum calcium concentration in a double-blind, randomized, placebo-controlled study. After only 8 weeks, serum calcium and bone turnover markers (serum NTX and osteocalcin) were reduced. After 4 weeks of discontinuation, no changes in serum calcium and PTH levels were observed, and bone turnover markers returned to their baseline values (168) (B-2B).

\section{Bisphosphonates}

Data from randomized controlled studies have consistently demonstrated that oral alendronate decreases bone turnover and increases BMD in patients with mild PHPT, although the effects on serum calcium have been inconsistent (169-171) (A-1B).

A randomized, double-blind, placebo-controlled study evaluated 40 postmenopausal women with PHPT who were randomized to receive alendronate $10 \mathrm{mg} /$ day or placebo for 48 weeks and followed for another 24 weeks after withdrawal of treatment. BMD was significantly higher in patients treated with alendronate $(+$ $4.17 \pm 6.01 \%$ vs. $-0.25 \pm 3.35 \%$ at the femoral neck, $\mathrm{p}=0.011)$ and $(+3.79 \pm 4.04 \%$ vs. $+0.19+/-2.8 \%$ at the lumbar spine, $\mathrm{p}=0.016)$. Mean serum calcium levels decreased slightly in the alendronate group, but not in the placebo group. Bone turnover markers also decreased in patients treated with alendronate. There

Table 10. Medical treatment and the effects on bone

\begin{tabular}{lccccc}
\hline Treatment & BMD $^{\mathbf{1}}$ & BTM $^{\mathbf{2}}$ & Serum calcium & Serum PTH \\
\hline Cinacalcet hydrochloride & No change & Increases & Decreases to normal often & Decreases slightly & Nevidence \\
Conjugated estrogen + medroxyprogesterone & Increases & Decreases & No change & No change \\
Raloxifene & $\mathrm{NA}^{4}$ & Decreases & Decreases & Decreases \\
Alendronate & Increases & Decreases & No change & No change \\
\hline
\end{tabular}

${ }^{1} \mathrm{BMD}$ : bone mineral density; ${ }^{2} \mathrm{BTM}$ : bone turnover markers; ${ }^{3} \mathrm{PTH}$ : parathyroid hormone; ${ }^{4} \mathrm{NA}$ : not available. 
were no significant differences in BMD at the distal $\mathrm{l} / 3$ radius in 48 weeks between the two groups (170) (A-1B).

In another multicenter, randomized, double-blind, placebo-controlled trial on 44 patients, treatment with alendronate over 2 years was associated with a significant increase in BMD at the lumbar spine in comparison with the baseline. Total hip BMD was significantly increased in 1 year and remained stable for 1 more year, and no significant differences in BMD at the distal radius were observed. After 1 year, patients receiving placebo, started on alendronate and similar changes in BMD were observed in the $2^{\text {nd }}$ year. Bone turnover markers decreased with the use of alendronate and serum $\mathrm{PTH}$, phosphate and ionized calcium levels did not change during the study (171) (A-1B).

In another randomized, placebo-controlled study, the effects of treatment with oral alendronate, $10 \mathrm{mg} /$ day or placebo, on BMD and biochemical markers of calcium and bone metabolism in elderly women with osteoporosis and mild PHPT were evaluated. Alendronate was significantly associated with a decrease in bone turnover markers and an increase in BMD by 8.6 $\pm 3.0 \%$ at the lumbar spine, $4.8 \pm 3.9 \%$ at total hip and $1.2 \pm 1.4 \%$ at total body, after 2 years. Serum calcium and phosphate and urinary calcium excretion decreased significantly during the first 3-6 months. A significant increase in serum PTH was seen during the first year of treatment (169) (B-2B).

\section{SUMMARY AND CONCLUSION}

Primary hyperparathyroidism continues to be an evolving disease in which several clinical profiles may be found. Most patients present with hypercalcemia in the asymptomatic form as an outpatient. Additional data on non-skeletal, non-classical manifestations such as fatigue, depression, decreased quality of life, diabetes and cardiovascular diseases, emerged in the literature during the last decade, but continue to be controversial if a casuality really exists. Normocalcemic primary hyperparathyroidism constitutes an additional challenge to the field as preliminary data suggest that it may progress with complications such as kidney stones without exhibiting hypercalcemia. The diagnosis is usually made by routine measurements of serum calcium during medical examination along with a high or inappropriate normal serum PTH levels. Normocalcemic primary hyperparathyroidism is usually detected with routine serum PTH measurements during an osteoporosis workup providing that secondary causes of an elevated serum PTH are excluded. The definite treatment for PHPT is parathyroidectomy and in hypercalcemic patients in whom the parathyroid lesion is not detected by imaging procedures, some surgical criteria have been employed to select those candidates. For those patients who present with contraindications for surgery or refuse the surgical procedure medical treatment can be an alternative. Cinacalcet, estrogen or bisphosphonates may be used in order to control serum calcium levels and to protect the skeleton.

Disclosure: no potential conflict of interest relevant to this article was reported.

\section{REFERENCES}

1. Bilezikian JP, Brandi ML, Rubin M, Silverberg SJ. Primary hyperparathyroidism: new concepts in clinical, densitometric and biochemical features. J Intern Med. 2005;257:6-17.

2. Bandeira FB, Griz L, Caldas G, Bandeira C, Freese E. From mild to severe primary hyperparathyroidism: the Brazilian experience. Arq Bras Endocrinol Metab. 2006;4:657-63.

3. Rodgers SE, Lew JI, Solórzano CC. Primary hyperparathyroidism. Curr Opin Oncol. 2008;20:52-8.

4. Eufrasino CS, Holanda NC, Prazeres PA, Bandeira F. Epidemiology of primary hyperparathyroidism and its nonclassical manisfestations in the city of Recife, Brazil. Endocr Rev. 2012;33:SUN-336.

5. Mayer D. Essential Evidence-Based Medicine. Cambridge: Cambridge University Press; 2004.

6. Ruda JM, Hollenbeak CS, Stack BC Jr. A systematic review of the diagnosis and treatment of primary hyperparathyroidism from 1995 to 2003. Otolaryngol Head Neck Surg. 2005;132(3):359-72.

7. Brandi ML, Falchetti A. Genetics of primary hyperparathyroidism. Urol Int. 2004;72(Suppl 1):11-6.

8. Brandi ML, Gagel RF, Angeli A, Bilezikian JP, Beck-Peccoz P, Bordi $C$, et al. Guidelines for diagnosis and therapy of MEN type 1 and type 2. J Clin Endocrinol Metab. 2001;86:5658-71.

9. Simonds WF, James-Newton LA, Agarwal SK, Yang B, Skarulis MC, Hendy GN, et al. Familial isolated hyperparathyroidism: clinical and genetic characteristics of thirty-six kindreds. Medicine (Baltimore). 2002;81:1-26.

10. Reh C, Hendy G, Cole DE, Jeandron DD. Neonatal hyperparathyroidism with heterozygous calcium-sensing receptor (CASR) R1850 mutation: clinical benefit from cinacalcet. J Clin Endocrinol Metab. 2011;96:707-12.

11. Tisell LE, Hansson G, Lindberg S, Ragnhult I. Hyperparathyroidism in persons treated with X-rays for tuberculous cervical adenitis. Cancer. 1977;40(2):846-54.

12. McMullen T, Bodie G, Gill A, Ihre-Lundgren C, Shun A, Bergin M, et al. Hyperparathyroidism after irradiation for childhood malignancy. Int J Radiat Oncol Biol Phys. 2009;73(4):1164.

13. Boehm BO, Rosinger S, Belyi D, Dietrich JW. The parathyroid as a target for radiation damage. N Engl J Med. 2011;365(7):676-8.

14. Schneider AB, Gierlowski TC, Shore-Freedman E, Stovall M, Ron E, Lubin J. Dose-response relationships for radiation-induced hyperparathyroidism. J Clin Endocrinol Metab. 1995;80(1):254-7. 
15. Tezelman S, Rodriguez JM, Shen W, Siperstein AE, Duh OY, Clark $\mathrm{OH}$. Primary hyperparathyroidism in patients who have received radiation therapy and in patients who have not received radiation therapy. J Am Coll Surg. 1995;180(1):81-7.

16. Wilson SD, Doffek KM, WangTS, Krzywda EA, Evans DB, Yen TW. Primary hyperparathyroidism with a history of head and neck irradiation: the consequences of associated thyroid tumors. Surgery. 2011;150(4):869-77.

17. Fjälling M, Dackenberg $A$, Hedman I, Tisell LE. An evaluation of the risk of developing hyperparathyroidism after 131 treatment for thyrotoxicosis. Acta Chir Scand. 1983;149(7):681-6.

18. Hsi ED, Zukerberg LR, Yang WI, Arnold A. Cyclin D1/PRAD1 expression in parathyroid adenomas: an immunohistochemical study. J Clin Endocrinol Metab. 1996;81(5):1736-9.

19. Rosenberg CL, Kim HG, Shows TB, Kronenberg HM, Arnold A. Rearrangement and overexpression of D11S287E, a candidate oncogene on chromosome 11q13 in benign parathyroid tumors. Oncogene. 1991;6(3):449-53.

20. Hemmer S, Wasenius VM, Haglund C, Zhu Y, Knuutila S, Franssila $\mathrm{K}$, et al. Deletion of 11q23 and cyclin D1 overexpression are frequent aberrations in parathyroid adenomas. Am J Pathol. 2001;158(4):1355-62.

21. Vasef MA, Brynes RK, Sturm M, Bromley C, Robinson RA. Expression of cyclin D1 in parathyroid carcinomas, adenomas, and hyperplasias: a paraffin immunohistochemical study. Mod Pathol. 1999;12(4):412-6.

22. Pausova Z, Soliman E, Amizuka N, Janicic N, Konrad EM, Arnold $A$, et al. Role of the RET proto-oncogene in sporadic hyperparathyroidism and in hyperparathyroidism of multiple endocrine neoplasia type 2. J Clin Endocrinol Metab. 1996;81(7):2711-8.

23. Padberg BC, Schröder S, Jochum W, Kastendieck H, Roth J, Heitz $\mathrm{PU}$, et al. Absence of RET proto-oncogene point mutations in sporadic hyperplastic and neoplastic lesions of the parathyroid gland. Am J Pathol. 1995;147(6):1600-7.

24. Carling T, Correa P, Hessman O, Hedberg J, Skogseid B, Lindberg $D$, et al. Parathyroid MEN1 gene mutations in relation to clinical characteristics of nonfamilial primary hyperparathyroidism. J Clin Endocrinol Metab. 1998;83(8):2960-3.

25. Farnebo F, Teh BT, KytöläS, Svensson A, Phelan C, Sandelin K, at al. Alterations of the MEN1 gene in sporadic parathyroid tumors. J Clin Endocrinol Metab. 1998;83(8):2627-30.

26. Samander EH, Arnold A. Mutational analysis of the vitamin D receptor does not support its candidacy as a tumor suppressor gene in parathyroid adenomas. J Clin Endocrinol Metab. 2006;91(12):5019-21.

27. Rao DS, Honasoge M, Divine GW, Phillips ER, Lee MW, Ansari $M R$, et al. Effect of vitamin D nutrition on parathyroid adenoma weight: pathogenetic and clinical implications. J Clin Endocrinol Metab. 2000;85(3):1054-8.

28. Björklund P, Akerström G, Westin G. Accumulation of nonphosphorylated beta-catenin and c-myc in primary and uremic secondary hyperparathyroid tumors. J Clin Endocrinol Metab. 2007;92(1):338-44.

29. Björklund P, Lindberg D, Akerström G, Westin G. Stabilizing mutation of CTNNB1/beta-catenin and protein accumulation analyzed in a large series of parathyroid tumors of Swedish patients. Mol Cancer. 2008;7:53.

30. Fraser, W. Hyperparathyroidism. Lancet. 2009;374:145-58.

31. Pallan S, Khan A. Primary hyperparathyroidism. Can Fam Physician. 2011;57:184-9.

32. Christensen $S$, Nissen $P H$, Vestergaard $P$, Heickendorff $L$, Brixen $K$, Mosekilde L. Discriminative power of three indices of renal calcium excretion for the distinction between familial hypocalciuric hypercalcaemia and primary hyperparathyroidism: a follow-up study on methods. Clin Endocrinol (Oxf). 2008;69(5):713-20.

33. Mackenzie-Feder J, Sirrs S, Anderson D, Sharif J, Khan A. Primary hyperparathyroidism: an overview. Int $\mathrm{J}$ Endocrinol. 2011;2011:251410.

34. Yu N, Donnan PT, Murphy MJ, Leese GP. Epidemiology of primary hyperparathyroidism in Tayside, Scotland, UK. Clinical Endocrinology. 2009;71:485-93.

35. Andrade LD, Marques TF, Diniz ET, Lucena CS, Griz L, Bandeira F. Impact of the use of hydrochlorothiazide in secretion PTH in hypertensive patients. Arq Bras Endocrinol Metab. 2010;54(Supl 5):S491.

36. Eastell R, Arnold A, Brandi ML, Brown EM, D'Amour P, Hanley DA, et al. Diagnosis of asymptomatic primary hyperparathyroidism: proceedings of the third international workshop. J Clin Endocrinol Metab. 2009;94(2):340-50.

37. Pradeep PV, Jayashree B, Mishra A, Mishra SK. Systematic review of primary hyperparathyroidism in India: the past, present and the future trends. Int J Endocrinol. 2011;2011:921814.

38. Gao P, Scheibel S, D'Amour P, John MR, Rao DS, Schmidt-Gayk H, et al. Development of a novel immunoradiometric assay exclusively for biologically active whole parathyroid hormone (1-84): implications for improvement of accurate assessment of parathyroid function. J Bone Miner Res. 2001;16:605-14.

39. Silverberg SJ, Gao P, Brown I, Logerfo P, Cantor TL, Bilezikian JP. Clinical utility of an immunoradiometric assay for parathyroid hormone (1-84) in primary hyperparathyroidism. J Clin Endocrinol Metab. 2003;88:4725-30.

40. Carnevale V, Dionisi S, Nofroni I, Romagnoli E, Paglia F, De Geronimo $S$, et al. Potential clinical utility of a new IRMA for parathyroid hormone in postmenopausal patients with primary hyperparathyroidism. Clin Chem. 2004;50:626-31.

41. Boudou P, Ibrahim F, Cormier C, Chabas A, Sarfati E, Souberbielle JC. Third- or second-generation parathyroid hormone assays: a remaining debate in the diagnosis of primary hyperparathyroidism. J Clin Endocrinol Metab. 2005;90:6370-2.

42. Bringhurst FR. Circulating forms of parathyroid hormone: peeling back the onion. Clin Chem. 2003;49:1973-5.

43. Bandeira F, Caldas G, Freese E, Griz L, Faria M, Bandeira C. Relationship between vitamin $D$ serum status and clinical manifestations of primary hyperparathyroidism. Endocr Pract. 2002;8:266-70.

44. Suh J, Cronan JJ, Monchik JM. Primary hyperparathyroidism: is there an increased prevalence of renal stone disease? AJR Am J Roentgenol. 2008;191(3):908-11.

45. Rejnmark L, Vestergaard P, Mosekilde L. Nephrolithiasis and renal calcifications in primary hyperparathyroidism. J Clin Endocrinol Metab. 2011;96(8):2377-85.

46. Amaral LMB, Queiroz DC, Marques TF, Mendes M, Bandeira F. Normocalcemic versus hypercalcemic primary hyperparathyroidism: more stone than bone? J Osteoporos. 2012;2012:128352.

47. Marques TF, Vasconcelos R, Diniz E, Rêgo D, Griz L, Bandeira F. Normocalcemic primary hyperparathyroidism in clinical practice: an indolent condition or a silent threat? Arq Bras Endocrinol Metabol. 2011;55(5):314-7.

48. Khan A, Bilezikian JP. Primary hyperparathyroidism: pathophysiology and impact on bone. CMAJ. 2000;163(2):184-7.

49. Silverberg SJ, Lewiecki EM, Mosekilde L, Peacock M, Rubin MR. Presentation of asymptomatic primary hyperparathyroidism: proceedings of the Third International Workshop. J Clin Endocrinol Metab. 2009;94:351-65.

50. Valdemarsson S, Lindergard B, Tibblin S, Bergenfelz A. Increased biochemical markers of bone formation and resorption in primary hyperparathyroidism with special reference to patients with mild disease. J Intern Med. 1998;243:115-22. 
51. Roschger P, Dempster DW, Zhou H, Paschalis EP, Silverberg SJ, Shane $E$, et al. New observations on bone quality in mild primary hyperparathyroidism as determined by quantitative backscattered electron imaging. J Bone Miner Res. 2007;22:717-23.

52. Siilin $H$, Lundgren $E$, Mallmin H, Mellström D, Ohlsson C, Karlsson $\mathrm{M}$, et al. Prevalence of primary hyperparathyroidism and impact on bone mineral density in elderly men: MrOs Sweden. World J Surg. 2011;35(6):1266-72.

53. Vignali E, Viccica G, Diacinti D, Cetani F, Cianferotti L, Ambrogini $\mathrm{E}$, et al. Morphometric vertebral fractures in postmenopausal women with primary hyperparathyroidism. J Clin Endocrinol Metab. 2009;94(7):2306-12.

54. Khosla S, Melton Jr, Wermers RA, Crowson CS, O'Fallon W, Riggs B. Primay hyperparathyroidism and the risk of fracture: a population-based study. J Bone Miner Res. 1999;14(10):1700-7.

55. TamuraY, Araki A, ChibaY, Mori S, Hosoi T, HoriuchiT. Remarkable increase in lumbar spine bone mineral density and amelioration in biochemical markers of bone turnover after parathyroidectomy in elderly patients with primary hyperparathyroidism: a 5-year follow-up study. J Bone Miner Metab. 2007;25:226-31.

56. Rubin MR, Bilezikian JP, McMahon DJ, Jacobs T, Shane E, Siris $E$, et al. The natural history of primary hyperparathyroidism with or without parathyroid surgery after 15 years. J Clin Endocrinol Metab. 2008;93:3462-70.

57. Rao DS, Philips ER, Divind GW, Talpos GB. Randomized controlled clinical trial of surgery versus no surgery in patients with mild asymptomatic primary hyperparathyroidism. J Clin Endocrinol Metab. 2004;89:5415-22.

58. VanderWalde LH, Liu IL, Haigh PI. Effect of bone mineral density and parathyroidectomy on fracture risk in primary hyperparathyroidism. World J Surg. 2009;33(3):406-11.

59. Cusano N, Wang P, Cremers S, Haney E, Bauer D, Orwoll E, et al. Subclinical hypoparathyroidism: a new variant based upon a cohort from MrOS. J Bone Miner Res. 2011;26(Suppl1):S183.

60. Eriksen E. Primary hyperparathyroidism: lessons from bone histomorphometry. J Bone Miner Res. 2002;17:N95-7.

61. Dempster DW, Muller R, Zhou H, Kohler T, Shane E, Parisien M, et al. Preserved three-dimensional cancellous bone structure in mild primary hyperparathyroidism. Bone. 2007;41:19-24.

62. Charopoulos I, Tournis S, Trovas G, Raptou P, Kaldrymides P, Skarandavos $\mathrm{G}$, et al. Effect of primary hyperparathyroidism on volumetric bone mineral density and bone geometry assessed by peripheral quantitative computed tomography in postmenopausal women. J Clin Endocrinol Metab. 2006;91:1748-53.

63. Joborn C, Hetta J, Johansson H, Rastad J, Agren H, Akerström $\mathrm{G}$, et al. Psychiatric morbidity in primary hyperparathyroidism. World J7 Surg. 1988;12:476-81.

64. Silverberg SJ. Non-classical target organs in primary hyperparathyroidism. J Bone Miner Res. 2002;17(suppl .2):N117-25.

65. Yu N, Donnan PT, Flynn RW, Murphy MJ, Smith D, Rudman A. Increased mortality and morbidity in mild primary hyperparathyroid patients. The parathyroid epidemiology and audit research study (PEARS). Clin Endocrinol. 2010;73:30-4.

66. Coker LH, Rorie K, Cantley L, Kirkland K, Stump D, Burbank N, et al. Primary hyperparathyroidism, cognition, and health-related quality of life. Ann Surg. 2005;242(5):642-50.

67. Walker MD, McMahon DJ, Inabnet WB, Lazar RM, Brown I, Vardy $\mathrm{S}$, et al. Neuropsychological features in primary hyperparathyroidism: a prospective study. J Clin Endocrinol Metab. 2009;94(6):1951-8.

68. Bollerslev J, Jansson S, Mollerup CL, Nordenström J, Lundgren $E$, Tørring $O$, et al. Medical observation, compared with parathyroidectomy, for asymptomatic primary hyperparathyroidism: a prospective, randomized trial. J Clin Endocrinol Metab. 2007;92(5):1687-92.
69. Ambrogini E, Cetani F, Cianferotti L, Vignali E, Banti C, Viccica $\mathrm{G}$, et al. Surgery or surveillance for mild asymptomatic primary hyperparathyroidism: a prospective, randomized clinical trial. J Clin Endocrinol Metab. 2007;92(8):3114-21.

70. Conri C, Ducloux G, Lagueny A, Ferrer M, Vital C. Polyneuropathy in type I multiple endocrine syndrome. Presse Med. 1990;19(6):247-50.

71. Eufrazino CSS, Bandeira F, et al. Peripheral polyneuropathy associated with primary hyperparathyroidism. Arq Bras Endocrinol Metab. 2008;52(Suppl.6):976.

72. Moskal W. Severe sensorimotor polyneuropathy in primary hyperparathyroidism. Neurol Neurochir Pol. 1999;33(6):1443-7.

73. Logullo F, Babbini MT, Di Bella P, Provinciali L. Reversible combined cognitive impairment and severe polyneuropathy resulting from primary hyperparathyroidism. Ital J Neurol Sci. 1998;19(2):86-9.

74. Olukoga A. Lessons to be learned: a case study approach. Primary hyperparathyroidism simulating an acute severe polyneuritis. J R Soc Health. 1998;118(2):103-6.

75. Patten BM, Bilezikian JP, Mallette LE, Prince A, Engel WK, Aurbach GD. Neuromuscular disease in primary hyperparathyroidism. Ann Intern Med. 1974;80(2):182-93.

76. Turken SA, Cafferty M, Silverberg SJ, De La Cruz L, Cimino C, Lange DJ, et al. Neuromuscular involvement in mild, asymptomatic primary hyperparathyroidism. Am J Med. 1989;87(5):553-7.

77. Chou FF, Sheen-Chen SM, Leong CP. Neuromuscular recovery after parathyroidectomy in primary hyperparathyroidism. Surgery. 1995;117(1):18-25.

78. Bilezikian JP, Khan AA, Potts JT. Guidelines for the management of asymptomatic primary hyperparathyroidism: summary statement from the Third International Workshop. J Clin Endocrinol Metab. 2009;94:335-9.

79. Luboshitzky R, Chertok-Schaham Y, Lavi I, Ishay A. Cardiovascular risk factors in primary hyperparathyroidism. J Endocrinol Invest. 2009;32:317-21.

80. Palmer M, Adami HO, Bergstrom R, Akerstrom G, Ljunghall S. Mortality after surgery for primary hyperparathyroidism: a follow-up of 441 patients operated on from 1956 to 1979. Surgery. 1987;102:1-7.

81. Ronni-Sivula H. Causes of death in patients previously operated on for primary hyperparathyroidism. Ann Chir Gynaecol. 1985;74:13-8.

82. Hedback G, Tisell LE, Bengtsson BA, Hedman I, Oden A. Premature death in patients operated on for primary hyperparathyroidism. World J Surg. 1990;14:829-36.

83. Letizia C, Ferrari P, Cotesta D, Caliumi C, Cianci R, Cerci S, et al. Ambulatory monitoring of blood pressure (AMBP) in patients with primary hyperparathyroidism. J Hum Hypertens. 2005;19(11):901-6.

84. Heyliger A, Tangpricha V, Weber C, Sharma J. Parathyroidectomy decreases systolic and diastolic blood pressure in hypertensive patients with primary hyperparathyroidism. Surgery. 2009;146(6):1042-7.

85. Lind L, Jacobsson S, Palmer M, Lithell $\mathrm{H}$, Wengle B, Ljunghall $\mathrm{S}$. Cardiovascular risk factors in primary hyperparathyroidism: a 15year follow-up of operated and unoperated cases. J Intern Med. 1991;230:29-35.

86. Dalberg K, Brodin LA, Juhlin-Dannfelt A, Farnebo LO. Cardiac function in primary hyperparathyroidism before and after operation. An echocardiographic study. Eur J Surg. 1996;162:171-6.

87. Piovesan A, Molineri N, Casasso F, Emmolo I, Ugliengo G, Cesario $F$, et al. Left ventricular hypertrophy in primary hyperparathyroidism. Effects of successful parathyroidectomy. Clin Endocrinol (Oxf). 1999;50:321-28. 
88. Almqvist EG, Bondeson AG, Bondeson L, Nissborg A, Smedgard $P$, Svensson SE. Cardiac dysfunction in mild primary hyperparathyroidism assessed by radionuclide angiography and echocardiography before and after parathyroidectomy. Surgery. 2002;132:1126-32.

89. Stefenelli T, Abela C, Frank H, Koller-Strametz J, Globits S, Bergler-Klein J, et al. Cardiac abnormalities in patients with primary hyperparathyroidism: implications for follow-up. J Clin Endocrinol Metab. 1997;82(1):106-12.

90. Vestergaard $\mathrm{P}$, Mollerup $\mathrm{CL}$, Frokjaer VG, Christiansen $\mathrm{P}, \mathrm{Bli}-$ chert-Toft M, Mosekilde L. Cardiovascular events before and after surgery for primary hyperparathyroidism. World J Surg. 2003;27:216-22.

91. Rubin MR, Maurer MS, McMahon DJ, Bilezikian JP, Silverberg SJ. Arterial stiffness in mild primary hyperparathyroidism. J Clin Endocrinol Metab. 2005;90(6):3326-30.

92. Smith JC, Page MD, John R, Wheeler MH, Cockcroft JR, Scanlon $\mathrm{MF}$, et al. Augmentation of central arterial pressure in mild primary hyperparathyroidism. J Clin Endocrinol Metab. 2000;85:3515-9.

93. Walker MD, Fleischer J, RundekT, McMahon DJ, Homma S, Sacco $R$, et al. Carotid vascular abnormalities in primary hyperparathyroidism. J Clin Endocrinol Metab. 2009;94(10):3849-56.

94. Ekmekci A, Abaci N, Ozbey NC, Agayev A, Aksakal N, Oflaz H, et al. Endothelial function and endothelial nitric oxide synthase intron $4 \mathrm{a} / \mathrm{b}$ polymorphism in primary hyperparathyroidism. J Endocrinol Invest. 2009;32:611-6.

95. Lind L, Ridefelt P, Rastad J, Akerstrom G, Ljunghall S. Cytoplasmic calcium regulation and the electrocardiogram in patients with primary hyperparathyroidism. Clin Physiol. 1994;14:103-10.

96. Stefenelli T, Mayr H, Bergler-Klein J, Globits S, Woloszczuk W, Niederle B. Primary hyperparathyroidism: incidence of cardiac abnormalities and partial reversibility after successful parathyroidectomy. Am J Med. 1993;95:197-202.

97. Marcocci C, Cetani F. Primary hyperparathyroidism. N Engl J Med. 2011;365:2389-97.

98. Schiffl H, Lang SM. Hypertension secondary to PHPT: cause or coincidence? Int J Endocrinol. 2011;2011:974647.

99. Walker MD, Fleischer JB, Di Tullio MR, Homma S, RundekT, Stein EM, et al. Cardiac structure and diastolic function in mild primary hyperparathyroidism. J Clin Endocrinol Metab. 2010;95(5): 2172-9.

100. Ishay A, Herer P, Luboshitzky R. Effects of successful parathyroidectomy on metabolic cardiovascular risk factors in patients with severe primary hyperparathyroidism. Endocr Pract. 2011;17(4):584-90.

101. Macfarlane DP, Yu N, Donnan PT, Leese GP. Should mild primary hyperparathyroidism be reclassified as insidious: is it time to reconsider? Clin Endocrinol. 2011;75(6):730-7.

102. Yu N, Donnan PT, Leeset GP. A record linkage study of outcomes in patients with mild primary hyperparathyroidism: the parathyroid epidemiology and audit research study (PEARS). Clin Endocrinol. 2011;75:160-76

103. Silverberg SJ, Bilezikian JP. Primary hyperparathyroidism. Endocrinology. 2001;1075-93.

104. Lowe H, McMahon DJ, Rubin MR, Bilezikian JP, Silverberg SJ. Normocalcemic primary hyperparathyroidism: further characterization of a new clinical phenotype. J Clin Endocrinol Metab. 2007;92:3001-5.

105. Silverberg SJ, Bilezikian JP. “Incipient" primary hyperparathyroidism: a "forme fruste" of an old disease. J Clin Endocrinol Metab. 2003;88(11):5348.

106. Kohri k, Takada M, Katoh Y, Kataoka K, Iguchi M, Yachiku S, et al. Parathyroid hormone and electrolytes during long-term treatment with allopurinol and thiazide. Br J Urol. 1987;59(6):503-7.
107. Cusano NE, Wang P, Cremers S, Haney E, Baure D, Orwoll E, et al. Asymptomatic normocalcemic primary hyperparathyroidism: characterization of a new phenotype of normocalcemic primary hyperparathtroidism. J Bone Miner Res. 2011;26(Suppl 1):S290.

108. Udelsman R, Pasieka JL, Sturgeon C, Young JE, Clark OH. Surgery for asymptomatic primary hyperparathyroidism: proceedings of the Third International Workshop. J Clin Endocrinol Metab. 2009;94:366-72.

109. Mohammadi A, Moloudi F, Ghasemi-rad M. The role of colour Doppler ultrasonography in the preoperative localization of parathyroid adenomas. Endocr J. 2012;59(5):375-82.

110. Bandeira FA, Oliveira RI, Griz LH, Caldas G, Bandeira C. Differences in accuracy of TC $99 m$ - Sestamibi scanning between severe and mild forms of primary hyperparathyroidism. J Nucl Med Technol. 2008;36:30-5.

111. Elaraj DM, Spippel RS, Lindsay S, Sansano I, Duh Q, Clark QH, et al. Are additional localization studies and referral indicated for patients with primary hyperparathyroidism who have negative Sestamib scan results? Arch Surg. 2010;145(6):578-81.

112. Chazen JL, Gupta A, Dunning A, Phillps CD. Diagnostic accuracy of $4 \mathrm{D}-\mathrm{CT}$ for parathyroid adenomas and hyperplasia. Am J Neuroradiol. 2012;33:429-33.

113. Rubin MR, Livolsi VA, Bandeira F, Caldas G, Bilezikian JP.Tc 99m-sestamibi uptake in osteitis fibrosa cystica simulating metastatic bone disease. J Clin Endocrinol Metab. 2001; 86(11):5138-41.

114. Carvalho JRP, Diniz ET, Marques TF, Lima TPM, Galamba L, Bandeira F. PTH measurement in the fine-needle aspirates from cervical nodules in primary hyperparathyroidism. Endocr Rev. 2011;32:P1-251.

115. Silverbeg Sj, Gartenberg F, Jacobs TP, Shane E, Siris E, Staron $\mathrm{RB}$, et al. Increased bone mineral density after parathyroidectomy in primary hyperparathyroidism. J Clin Endocrinol Metab. 1995;80:729-34.

116. Bollerslev J, Rosen T, Mollerup CL, Nordenstrom J, Baranowski $M$, Franco $C$, et al. Effect of surgery on cardiovascular risk factors in mild primary hyperparathyroidism. J Clin Endocrinol Metab. 2009;94:2255-61.

117. Silverberg SJ, Bilezikian JP. The diagnosis and management of asymptomatic primary hyperparathyroidism. Nat Clin Pract Endocrinol Metab. 2006;2(9):494-503.

118. Sankaran S, Gamble G, Bolland M, Reid IR, Grey A. Skeletal effects of interventions in mild primary hyperparathyroidism: a meta-analysis. J Clin Endocrinol Metab. 2010;95:1653-62.

119. Zanocco K, Heller M, Sturgeon C. Cost-efectiveness of parathyroidectomy for primary hyperparathyroidism. Endocr Pratc. 2011;17(Suppl1):69-74.

120. Stavrakis Al, Ituarte $\mathrm{PH}, \mathrm{Ko} \mathrm{CY}$, Yeh MW. Surgeon volume as a predictor of outcomes in inpatient and outpatient endocrine surgery. Surgery. 2007;142:887-99.

121. Zanocco K, Sturgeon C. How should age at diagnosis impact treatment strategy in asymptomatic primary hyperparathyroidism? A cost-effectiveness analysis. Surgery. 2008;144:290-8.

122. Allendorf J, DiGorgi M, Spanknebel K, Inabnet W, Chabot J, Logerfo P. 1112 consecutive bilateral neck explorations for primary hyperparathyroidism. World J Surg. 2007;31:2075-80.

123. Udelsman R, Donovan PI, Sokoll LJ. One hundred consecutive minimally invasive parathyroid explorations. Ann Surg. 2000;232:331-9.

124. Agarwal G, Barraclough BH, Reeve TS. Minimally invasive parathyroidectomy using the "focused" lateral approach. II. Surgical technique. Aust N Z J Surg. 2002;72:147-51.

125. Rubello D, Mariani G, Pelizzo MR. Minimally invasive radio-guided parathyroidectomy on a group of 452 primary hyperparathyroid patients: refinement of preoperative imaging and intraoperative procedure. Nuklearmedizin. 2007;46(3):85-92. 
126. Melck AL, Armstrong MJ, Yip L, Carty SE. Case-controlled comparison of video-assisted and conventional minimally invasive parathyroidectomy. Am Surg. 2012;78(1):125-32.

127. Dobrinja C, Trevisan G, Liguori G. Minimally invasive video-assisted parathyroidectomy. Initial experience in a General Surgery Department. J Endocrinol Invest. 2009;32(2):130-3.

128. Lombardi CP, Raffaelli M, Traini E, De Crea C, Corsello SM, Bellantone R. Video-assisted minimally invasive parathyroidectomy: benefits and longterm results. World J Surg. 2009;33:2266-81.

129. Bergenfelz A, Kanngiesser V, Zielke A, Nies C, Rothmund M. Conventional bilateral cervical exploration versus open minimally invasive parathyroidectomy under local anaesthesia for primary hyperparathyroidism. Br J Surg. 2005;92(2):190-7.

130. Westerdahl J, Bergenfelz A. Unilateral versus bilateral neck exploration for primary hyperparathyroidism: five-year follow-up of a randomized controlled trial. Ann Surg. 2007;246:976-81.

131. Russell CF, Dolan SJ, Laird JD. Randomized clinical trial comparing scan-directed unilateral versus bilateral cervical exploration for primary hyperparathyroidism due to solitary adenoma. $\mathrm{Br} \mathrm{J}$ Surg. 2006;93:418-21.

132. Bergenfelz A, Lindblom $P$, Tibblin S, Westerdahl J. Unilateral versus bilateral neck exploration for primary hyperparathyroidism: a prospective randomized controlled trial. Ann Surg. 2002;236(5):543-51.

133. Slepavicius A, Beisa V, Janusonis V, Strupas K. Focused versus conventional parathyroidectomy for primary hyperparathyroidism: a prospective, randomized, blinded trial. Langenbecks Arch Surg. 2008;393(5):659-66.

134. Utiger RD. Treatment of primary hyperparathyroidism. N Engl J Med. 1999;341(17):1301-2.

135. Silverberg SJ, Shane E, Bilezikian JP. A 10-year prospective study of primary hyperparathyroidism with or without parathyroid surgery. N Engl J Med. 1999;341:1249-55.

136. Kaji H, Yamauchi M, Nomura R, Sugimoto T. Improved peripheral cortical bone geometry after surgical treatment of primary hyperparathyroidism in postmenopausal women. J Clin Endocrinol Metab. 2008;93:3045-50.

137. Talpos GB, Bone HG 3rd, Kleerekoper M, Phillips ER, Alam M, Honasoge $M$, et al. Randomized trial of parathyroidectomy in mild asymptomatic primary hyperparathyroidism: patient description and effects on the SF-36 health survey. Surgery. 2000;128(6):1013-20.

138. Silverberg SJ, Locker FG, Bilezikian JP. Vertebral osteopenia: a new indication for surgery in primary hyperparathyroidism. $J$ Clin Endocrinol Metab. 1996;81(11):4007-12.

139. Nomura $R$, Sugimoto $T$, Tsukamoto T, Yamauchi M, Sowa $H$, Chen $\mathrm{Q}$, et al. Marked and sustained increase in bone mineral density after parathyroidectomy in patients with primary hyperparathyroidism; a six-year longitudinal study with or without parathyroidectomy in a Japanese population. Clin Endocrinol (Oxf). 2004;60(3):335-42.

140. Silverberg SJ, Gartenberg F, Jacobs TP, Shane E, Siris E, Staron $\mathrm{RB}$, et al. Longitudinal measurements of bone density and biochemical indices in untreated primary hyperparathyroidism. $\mathrm{J}$ Clin Endocrinol Metab. 1995;80(3):723-8.

141. Parisien M, Cosman F, Mellish RW, Schnitzer M, Nieves J, Silverberg $\mathrm{SJ}$, et al. Bone structure in postmenopausal hyperparathyroid, osteoporotic, and normal women. J Bone Miner Res. 1995;10(9):1393-9.

142. Ayturk S, Gursoy A, BascilTutuncu N, Ertugrul DT, Guvener Demirag $\mathrm{N}$. Changes in insulin sensitivity and glucose and bone metabolism over time in patients with asymptomatic primary hyperparathyroidism. J Clin Endocrinol Metab. 2006;91(11):4260-3.

143. Guo CY, Thomas WE, al-Dehaimi AW, Assiri AM, Eastell R. Longitudinal changes in bone mineral density and bone turnover in postmenopausal women with primary hyperparathyroidism. $\mathrm{J}$ Clin Endocrinol Metab. 1996;81(10):3487-91.
144. Grey AB, Stapleton JP, Evans MC, Tatnell MA, Reid IR. Effect of hormone replacement therapy on bone mineral density in postmenopausal women with mild primary hyperparathyroidism. A randomized, controlled trial. Ann Intern Med. 1996;125(5):360-8.

145. Wilson RJ, Rao S, Ellis B, Kleerekoper M, Parfitt AM. Mild asymptomatic primary hyperparathyroidism is not a risk factor for vertebral fractures. Ann Intern Med. 1988;109(12):959-62.

146. Vestergaard P, Mosekilde L. Cohort study on effects of parathyroid surgery on multiple outcomes in primary hyperparathyroidism. BMJ. 2003;327(7414):530-4.

147. Vestergaard P, Mollerup CL, Frøkjaer VG, Christiansen P, Blichert-Toft M, Mosekilde L. Cohort study of risk of fracture before and after surgery for primary hyperparathyroidism. BMJ. 2000;321(7261):598.

148. Prager G, Kalaschek A, Kaczirek K, Passler C, Scheuba C, Sonneck $\mathrm{G}$, et al. Parathyroidectomy improves concentration and retentiveness in patients with primary hyperparathyroidism. Surgery. 2002;132:930-6.

149. Roman SA, Sosa JA, Mayes L, Desmond E, Boudourakis L, Lin R, et al. Parathyroidectomy improves neurocognitive deficits in patients with primary hyperparathyroidism. Surgery. 2005;138:1121-9.

150. Walker MD, Silverberg SJ. Parathyroidectomy in asymptomatic primary hyperparathyroidism: improves "bones" but not “psychic moans". J Clin Endocrinol Metab. 2007;92(5):1613-5.

151. Scholz DA, Purnell DC. Asymptomatic primary hyperparathyroidism. 10-year prospective study. Mayo Clin Proc. 1981;56(8):473-8.

152. Hedback $M$, Odén $S$. Cardiovascular disease, hypertension and renal function in primary hyperparathyroidism. J Intern Med. 2002;251:476-83.

153. Persson A, Bollerslev J, Rosen $T$, Mollerup CL, Franco C, Isaksen GA, et al. Effect of surgery on cardiac structure and function in mild primary hyperparathyroidism. Clin Endocrinol (Oxf). 2011;74:174-80.

154. Farahnak P, Ring M, Caidahl K, Farnebo LO, Eriksson MJ, Nilsson $\mathrm{IL}$, et al. Cardiac function in mild primary hyperparathyroidism and the outcome after parathyroidectomy. Eur $\mathrm{J}$ Endocrinol. 2010;163:461-7.

155. Roman SA, Sosa JA, Pietrzak RH, Snyder PJ, Thomas DC, Udelsman $R$, et al. The effects of serum calcium and parathyroid hormone changes on psychological and cognitive function in patients undergoing parathyroidectomy for primary hyperparathyroidism. Ann Surg. 2011;253(1):131-7.

156. Clerici T, Brandle M, Lange J, Doherty GM, Gauger PG. Impact of intraoperative parathyroid hormone monitoring on the prediction of multiglandular parathyroid disease. World J Surg. 2004;28(2):187-92.

157. Ohe MN, Santos RO, Kunii IS, Abrahão M, Cervantes O, Carvalho $A B$, et al. Utilidade da medida de PTH intra-operatório no tratamento cirúrgico do hiperparatiroidismo primário e secundário: análise de 109 casos. Arq Bras Endocrinol Metab. 2006;50(5):869-75.

158. Barczynski M, Konturek A, Cichon S, Hubalewska-Dydejczyk A, Golkowski F, et al. Intraoperative parathyroid hormone assay improves outcomes of minimally invasive parathyroidectomy mainly in patients with a presumed solitary parathyroid adenoma and missing concordance of preoperative imaging. Clin Endocrinol (Oxf). 2007;66(6):878-85.

159. Hwang RS, Morris LF, Ro K, Park S, Ituarte PH, Hong JC, et al. A selective, Bayesian approach to intraoperative PTH monitoring. Ann Surg. 2010;251(6):1122-6.

160. Bergenfelz AO, Jansson SK, Wallin GK, Mårtensson HG, Rasmussen $\mathrm{L}$, Eriksson HL, et al. Impact of modern techniques on short-term outcome after surgery for primary hyperparathyroidism: a multicenter study comprising 2,708 patients. Langenbecks Arch Surg. 2009;394(5):851-60. 
161. Miccoli P, Berti P, Materazzi G, Ambrosini CE, Fregoli L, Donatini G. Endoscopic bilateral neck exploration versus quick intraoperative parathormone assay (qPTHa) during endoscopic parathyroidectomy: a prospective randomized trial. Surg Endosc. 2008;22:398-400.

162. Vestergaard P. Current pharmacological options for the management of primary hyperparathyroidism. Drugs. 2006;66(17):2189211.

163. Bollerslev J, Marcocci C, Sosa M, Nordenström J, Bouillon R, Mosekilde L. Current evidence for recommendation of surgery, medical treatment and vitamin $D$ repletion in mild primary hyperparathyroidism. Eur J Endocrinol. 2011;165):851-64.

164. Peacock M, Bilezikian JP, Klasssen PS, Guo MD, Turner SA, Shoback $D$. Cinacalcet hydrochloride maintains long-term normocalcemia in patients with primary hyperparathyroidism. J Clin Endocrinol Metab. 2005;90(1):135-41.

165. Peacock M, Bolognese MA, Borofsky M, Scumpia S, Sterling LR, Cheng $S$. Cinacalcet treatment of primary hyperparathyroidism: biochemical and bone densitometric outcomes in a five-year study. J Clin Endocrinol Metab. 2009;94(12):4860-7.

166. Marcocci C, Chanson P, Shoback D, Bilezikian J, Fernandez-Cruz $\mathrm{L}$, Orgiazzi J, et al. Cinacalcet reduces serum calcium concentra- tions in patients with intractable primary hyperparathyroidism. J Clin Endocrinol Metab. 2009;94(8):2766-72.

167. Orr-Walker BJ, Evans MC, Clearwater JM, Horne A, Grey AB, Reid IR. Effect of hormone replacement therapy on bone mineral density in postmenopausal women with primary hyperparathyroidism: four-year follow-up and comparison with healthy postmenopausal women. Arch Intern Med. 2000;160:2161-6.

168. Rubin MR, Lee KH, McMahon DJ, Silverberg SJ. Raloxifene Iowers serum calcium and markers of bone turnover in postmenopausal women with primary hyperparathyroidism. J Clin Endocrinol Metab. 2003;88:1174-8.

169. Rossini M, Gatti D, Isaia G, Sartori L, Braga V, Adami S. Effect of oral alendronate in elderly patients with osteoporosis and mild primary hyperparathyroidism. J Bone Miner Res. 2001;16:113-9.

170. Chow CC, Chan WB, Li JK, Chan NN, Chan MH, Ko GT. Oral alendronate increases bone mineral density in postmenopausal women with primary hyperparathyroidism. J Clin Endocrinol Metab. 2003;88:581-7.

171. Khan AA, Bilezikian JP, Kung AW, Ahmed MM, Dubois SJ, Ho AY, et al. Alendronate in primary hyperparathyroidism: a double-blind, randomized, placebo-controlled trial. J Clin Endocrinol Metab. 2004;89:3319-25. 